\title{
JOB LOSS AND EFFECTS ON FIRMS AND WORKERS
}

\author{
Kevin F. Hallock, Michael R. Strain and Douglas Webber* \\ Cornell University
}

June 9, 2011

Kevin Hallock is Professor and Chair of the Department of Labor Economics, Professor of Human Resource Studies and Director of The Institute for Compensation Studies in the ILR School at Cornell University and Research Associate at the National Bureau of Economic Research. Michael Strain and Douglas Webber are Ph.D. students in Economics at Cornell University.

We are grateful to David Autor, Sherrilyn Billger, Kristin Butcher, David Clark, Henry Farber, Felice Klein, Harold Oaklander, Tim Taylor and Olga Yakusheva for many helpful suggestions on work leading to this paper. Michelle Arthur, Sara Christopher, John Deke, Erica Field, Charles Fields, Clayton Reck, Martha Schniepp, and Kristen Stanton provided excellent research assistance in collecting some of the data. This paper draws on, among others, Hallock (2006) and Hallock (2009) for which permission has been granted from Emerald Group Publishing Limited and The American Economic Association, respectively to use portions in this work. 


\begin{abstract}
This paper serves as an introduction and (incomplete) survey of the wide-ranging literature on job loss. We begin with a discussion of job stability in the US and the commitment between firms and workers, and how this has changed in recent years. We then focus on the short and long-term consequences to workers (i.e. wages, health outcomes) following a layoff, and the effect which mass layoffs have on future firm performance. The changing nature of these relationships over the past several decades is a central theme of this paper. We review the common data sources used to examine these questions, and identify many influential papers on each topic. Additionally, we discuss alternative policies to the typical mass layoff, such as worksharing.
\end{abstract}


Job loss is painful. There are thousands of individual stories of workers who lose their jobs each year from all parts of the world ${ }^{1}$. A great deal of work across the social sciences examines the causes and consequences of job loss. This chapter considers a small part of that work and specifically focuses on the effects of job loss on workers (including the effects on subsequent wages and on health) and on the effects of job loss on companies (including short- and longer-run corporate performance). It also considers other questions such as whether firms are less committed to workers and workers less committed to firms than they were in the recent past, considers a variety of data sources for research on job loss, and considers alternatives to job loss and various public policies in the United States and throughout the world.

To begin, it should be noted that this paper will not focus on other important issues related to job loss. It will not examine, in significant detail, the effects of international trade or tariffs. The paper is also not about labor turnover that is initiated by the worker. Voluntary quits and separations are not discussed, nor are firings for cause or strictly for performance.

The paper examines instances where companies layoff employees (temporarily or permanently, although the focus is on the later). It examines changes in the displacement of workers over time, reasons for the changes and effects of workers and companies. There is also a focus on policies to consider whether there can be improvements to what is known and done about job loss, and a discussion of how other countries handle reductions in the demand for labor.

\section{Introduction, Data Sources, and Roadmap}

This section of the paper outlines various important data sources for the study of job loss in the United States. It also provides an outline of the rest of the paper.

\footnotetext{
${ }^{1}$ See Uchitelle (2006) and Uchitelle and Kleinfeld (1996) for examples.
} 


\section{Description of Some of the Data on Job Loss}

A wide variety of datasets have been used to examine the causes, consequences, and characteristics of layoffs. One of the most popular data sources is the Current Population Survey (CPS), administered by the Bureau of Labor Statistics (BLS), which is a common source for many labor market statistics. In addition to the survey questions relating to worker displacement in the standard monthly CPS, the BLS also makes available a CPS Displaced Worker Supplement, which contains detailed questions specifically tailored to worker displacement. The CPS Displaced Worker Survey began in 1984 and is conducted every two years. Examples of clever use the survey include Farber $(1999,2005$, and 2011).

Another commonly used dataset is the Survey of Income and Program Participation (SIPP). Unlike the CPS, the SIPP contains short panels on respondents. For researchers interested in the healthrelated consequences of layoffs, the Health and Retirement Survey (HRS) contains among the most detailed health questions of any dataset. Additionally, many of the responses are verified by a doctor to avoid self-reporting bias.

For many questions related to layoffs it is desirable to have long panels (repeated sampling of the same individuals over many years). One of the most commonly used panel datasets, the National Longitudinal Survey of Youth (NLSY), has two cohorts (beginning in 1979 and 1997) which are given detailed surveys every other year. Another popular source, the Panel Study of Income Dynamics (PSID), currently follows about 9,000 families. Panel data sources are necessary to answer questions about the long-term impact of layoffs, since they allow repeated questions with respect to job loss, job holding and income for the same individuals over time. Additionally, they provide researchers with additional statistical modeling choices, such as fixed-effects specifications.

This paper also discusses some studies conducted using individually collected data. For example, data from Billger and Hallock (2005), Hallock (2009), and Farber and Hallock (2009) include all job loss announcements published in the Wall Street Journal for any company ever in the Fortune 500 covering the years 1970-2007. 
Emerging data sources which could provide key insights into the long-term consequences of layoffs for both firms and individuals are linked employer-employee data. In the United States, the Longitudinal Employer Household Dynamics (LEHD) infrastructure covers nearly all (98\%) private US non-farm employment, and allows researchers to follow the employment behavior of workers and firms over time. Some work on mass layoffs has already been conducted using these data (e.g. Abowd, Mckinney and Vilhuber 2009).

\section{Definitions of job loss}

One complicating factor in the job loss literature is the degree of subjectivity with which job loss can be defined. From the point of view of the worker, the broadest definition of job loss is any involuntary separation from a job. This rules out voluntary quits, but includes all other job separations. Because workers who are fired for cause are often quite different from the rest of the workforce, the definition of job loss is typically restricted to layoffs.

Other important questions are the status (full-time/part-time) and how long the worker held the job before being laid off. For instance, the CPS displaced worker supplement distinguishes between workers who are long-tenured (three or more years at the same employer) or short-tenured (less than three years).

The reason for the layoff is also of interest. Many studies restrict their sample to layoffs which result from a plant closure in an attempt to avoid potential selection bias arising from the weakest workers being the first laid off. Although this definition could also suffer from selection bias if the plant closed because the average worker quality was lower than at other plants.

From the perspective of the firm, the definition of a layoff is similarly complicated. The researcher must choose a threshold by which to define a layoff event. This can be done in absolute terms (one-hundred workers laid off) or percentage terms (fifteen percent of a firm's labor force). 


\section{Roadmap for the Paper}

This paper is neither intended to be an exhaustive literature review of all that is known regarding job loss nor an exhaustive literature review of the subset of topics that we choose to discuss. It is intended to be a short description of a few areas and discussion of some work related to the effects of job loss on workers and on companies over the past several decades. Section II is an overview of job stability in the United States including an examination of changes in job stability over time and a consideration of whether it may be the case that firms are less committed to workers and workers are less committed to firms than they were in the not-too-distant past. Reasons for and alternatives to layoffs are discussed in Section III. Work-sharing is extensively examined in Section IV. Section V begins with an examination of the timing of job loss announcements and then goes on to discuss the effects of job loss on workers' subsequent employment and wages and long-term health outcomes. The results, on average, are not good news for workers who lose their jobs. The effects of job loss on companies are discussed in Section VI. This includes an analysis of the link between job loss announcements and CEO pay and CEO turnover and the short- and longer-run relationships between job loss and organizational performance. Concluding comments and some additional issues are discussed in Section VII.

\section{Job Stability in the United States}

Is the average worker in the United States with the same employer for fewer years than in the past? An important first issue is whether job stability has actually changed in the United States. If it has, for whom and why? This section will briefly examine this literature with significant emphasis on results from the Displaced Workers Supplement (DWS) of the Current Population Survey (CPS).

\section{Changes in job stability over time}

Henry Farber has written a series of very important papers (including Farber, 2005, 2007, 2008a, 2008 b and 2011) which clearly and carefully document changes in job stability over time. Some of this work considers whether one can use the Displaced Worker's Survey to actually identify all relevant job 
displacement (e.g. Farber, 2008a), some examines general trends in job loss in the United States (Farber, 2005) and some investigates the change in long-term worker-firm attachment (Farber 2007, 2008b).

Farber (2005) examines Displaced Workers Supplements (DWS) from 1984 - 2004 and has several important findings. First, more than $1 / 3$ of job losers are not employed at the next survey date (two years later). Second, about 13 percent of those who lost a full time job are subsequently holding part-time jobs. Third, on average, those who lose full-time jobs earn about 13 percent less on their new jobs, relative to the previous one. Fourth, he estimates that including the foregone earnings increases experienced by those who did not lose their jobs, those who lose full time jobs earn on the order of 17 percent less on their new jobs than they would have, had they not been displaced.

As for the interesting question of whether long-term employment has changed in the past decades, Farber (2007, 2008b) uses data from the Current Population Survey (CPS) from 1973 to 2006 by birth cohort to examine changes in the length of employment relationships. He finds that both (a) mean tenure and (b) fraction of workers working at least ten or at least twenty years at the same employer have each fallen ${ }^{2}$, particularly among male workers (as a result of growing commitment of women to the labor force and the fact that longer-term worker-firm relationships among women has, in fact, increased slightly during this period) (See Figures 1a and 1b). He also finds more of what he calls "churning," or shortterm jobs, defined as the fraction of workers whose job seniority is less than one year. He concludes that younger workers are much less likely than older workers to have a long-term job with the same employer.

The growing instability of employment relationships appears to have affected employees at various organization levels, and across industries. ${ }^{3}$ For example, Cappelli (1992) studies managerial displacement. Using the Displaced Workers Survey (DWS) he finds that, at least during the 1980s, "managers were actually more vulnerable to displacement than were other employees, suffering proportionately greater job loss from efforts to streamline and downsize organizations and from plant closings.” (p. 203). Chan and Stevens (2001) consider job loss among older workers. Using the Health

\footnotetext{
${ }^{2}$ Farber (2008a) finds that the drop in average job tenure and in long-term employment is primarily in the private sector and that there are some increases in long-term employment in the public sector.

${ }^{3}$ Also see Brown, Haltiwanger and Lane (2006) and Davis, Haltiwanger and Schuh (1996).
} 
and Retirement Study (HRS), they find that, for workers who lose jobs after age 55, the employment rate is 20 percentage points lower than the employment rate of similar workers who were not displaced. Elder (2004) studies this area with the same data sources and provides structural estimates of a dynamic search model. He finds that "simulations indicate that both market opportunities and age-related preferences for leisure are responsible for the observed unemployment durations, but that older workers would still have relatively long post-displacement jobless spells if preferences for leisure did not vary with age".

Given Farber's clear and convincing work, job stability in the United States has clearly changed in recent decades. Long job spells are clearly much less frequent than in the previous generation, although there is some variability by gender. The next section considers reasons for and potential alternatives to layoffs.

\section{Reasons for and Alternatives to Layoffs}

Why do firms execute layoffs? Are there alternatives to layoffs? Both of these questions are interesting and complicated. To begin, in this section we describe the reported reasons for job loss in more than 5,000 individual layoff events over the past 38 years (Also see Hallock, 2009). In the subsection that follows we discuss a variety of alternatives to layoffs. There also appears to be diversity in the kinds of political pressure, social sanctions and direct economic costs to employers across countries.

\section{Changes in Stated (by firms) Reasons for Job Loss}

In the past four decades there has been a quite substantial change in the reported reasons for job loss. Using a sample frame that included all firms that were ever in the Fortune 500 between 1970 and 2007, data on each job loss announcement described in the Wall Street Journal Index were recorded. For these 5,353 instances, the complete Wall Street Journal article was then read and a variety of information 
was collected. This information includes the primary, secondary and tertiary reason for the layoff, the number of workers effected and whether white or blue collar workers were included ${ }^{4}$.

Table 1 lists 18 reason categories for the job loss announcements. The table is arranged, for each "reason," in the following way: the first column shows data for all years, and the subsequent four columns relate to specific decades: 1970s, 1980s, 1990s, and 2000 - 2007. Clearly the category "demand slump" is most frequent, overall and in each decade. However, there is a substantial amount of variation over time. To see this more clearly, in the Figure 2, the "reasons" are grouped into six general categories: “reorganization," (reorganization, restructuring, and in-house merger), "plant closing," (leave market and plant closing), "slump in demand," (demand slump, excess supply, and structural), “cost issues," (cost control, posting losses, increase earnings and restore profitability), "other" (increased competition, merger, bankruptcy, strike and other), and "missing". While these groupings are, in some sense, arbitrary and other choices for groupings can easily be made, some dramatic changes over time are clearly visible in Figure 2. Note the scale is the same in each sub-figure, except for "slump in demand". The "slump in demand" category follows the business cycle quite closely with spikes around the times of the recessions in the early 1980s and 1990s and during the end of the high-tech "bubble". It is also interesting to note that job loss announcements categorized as being due to "reorganization" have changed quite a bit as a fraction of all announcements. Announcements due to "reorganization" became progressively more prevalent during the 1980s and 1990s, when some have argued that Wall Street wanted firms to get "lean" and encouraged firms to shrink employment (more on this below). However, the number of announcements categorized as "reorganization" dropped quite a bit in the early 2000s.

One might wonder about the quality of these "reported reasons" data. After all, the information likely came from a press release, to a reporter and then to a researcher. In order to consider the quality of the "reasons" data culled from newspaper accounts, 40 senior managers were interviewed about how they felt about the accuracy of the reasons stated in the Wall Street Journal in relation to the actual reasons for

\footnotetext{
${ }^{4}$ Billger and Hallock (2005) and Farber and Hallock (2009) use the first thirty years of this 38 -year data set. See those papers for more detail on the data construction.
} 
job loss. Many of their responses were interesting. Some felt that the reasons found in the paper were not very related to the actual reason for the announcement ${ }^{5}$ :

No. I don't believe them. Most of it seems to be management screwups. Senior Manager, Nondurable Goods Manufacturing

Businesses absolutely manipulate the reasons in the Wall Street Journal. But don't necessarily put a negative connotation on this word. You do everything you can to message. ... In the last year, there was almost no negative connotation of layoffs. Firms can make massive layoffs with almost no repercussions. COO, High Tech

Every meeting we go to we talk about a layoff or a downsizing, whatever the [expletive deleted] you want to call it ... Why does the CEO get any satisfaction from using the words we are compressing the size of company? Nobody ever wants to tell the truth. Senior Manager, Durable Goods Manufacturing

Should I have any confidence about what is said? No. Audiences are different. The Wall Street Journal is speaking to potential investors so the spin is to make opportunities to buy the company stock. Senior Manager, Durable Goods Manufacturing

No. Rarely. There is so much corporate speak ${ }^{6} . .$. It is all spun because the constituency is the current workforce, shareholders, consumers. Senior Manager, Nondurable Goods Manufacturing

They won't admit poor judgment. Some truth, but it doesn't include we screwed up. Senior Manager, Wholesale Trade

On the other hand, most respondents felt that the articles reported in the Wall Street Journal were not false but that some type of "spin" was put on them:

I never feel that the stated reasons are lies or incorrect. But I do feel that they are never complete ... The PR guy's job is to describe that the glass is half full. Senior Manager, High Tech

I think the companies are trying to collectively manage their image and investor confidence. I think they spin the information. I always wonder what is really happening. That is the job of the reporter. I rarely think the company is lying. They just need to put the best light on it. Senior Manager, High Tech

\footnotetext{
${ }^{5}$ These quotes were earlier reported in Hallock (2006).

${ }^{6}$ O'Neil and Lenn (1995) note that middle managers' anger over layoffs "was directed at top managements' willingness to accept superficial slogans to justify the harsh reality of layoffs and corporate restructuring."
} 
Firms might take the most glamorous reason ... We would have a PR agency involved in layoffs and would craft that into what the market wanted to hear. ... As with all - layoffs are a scapegoat for poor performance. Weak managers. Senior Manager, High Tech

Well, I think as positive sounding as we can. We try to frame it in a positive light. It is a sad story. We try to emphasize that we are trying to do right by the employees. CFO, High Tech

Probably not accurately. We spin it a certain way and they take it from there. ... They accurately portrayed specific pieces. They spin it to make news. Senior Manager, High Tech

I guess, reasonably confident, that what is in the Wall Street Journal tells about 80 percent of the story, possibly... Typically what you see is all true. There just may be additional details. Senior Manager, Agriculture

\section{Alternatives to Layoffs}

There are several potential alternatives to layoffs. In this section, I will discuss many of them, including wage cuts, "voluntary" time off, paid sabbaticals and work outside the firm, early retirement, and voluntary work sharing. There is a long literature on the tradeoff between job loss and cuts in wages (see for example Bewley, 1999, who asks “Why Wages Don’t Fall During A Recession?”). One option for avoiding layoffs is to cut wages. Rather than cut ten percent of the workforce, a company could cut ten percent from the pool of compensation, across-the-board or otherwise. This may be a viable alternative for some organizations but it is difficult to tell at what point this would have to stop. Some companies argue that they would rather have a smaller, fully employed staff than a larger staff that is not working full-time and is, therefore, upset about potential lower earnings. Some organizations have turned to temporary help agencies and outsourcing as a way to help buffer the cyclical effects of employment demand at their firms (Autor, 2003). One questions is whether these are "good" jobs.

Some specific companies have tried to make attempts at alternatives to layoffs, but even these are not always sustainable. An example described in Cascio (2002) is Charles Schwab and Company, who in 2001 found their commission revenue 57 percent below a year earlier. The company tried many alternatives to layoffs: (1) delaying projects and cutting expenses like travel and entertainment, (2) senior 
executives taking pay cuts $^{7},(3)$ encouraging employees to take unused vacations and take unpaid leaves, and (4) designating certain Fridays as "voluntary" days off. In the end, the company did have to make layoffs to 2,000 of 25,000 employees but provided generous severance.

Cisco Systems is another example described in Cascio (2002). Cisco understood the value of goodwill and the importance of treating employees who were laid off well. When Cisco cut its workforce from 38,000 to 30,500 , it tried a program of paying employees one-third of their salaries and "lending" them to nonprofits for a year. This was a way for the company to keep in contact with employees in hope of avoiding re-training costs when demand increased. Cisco made a "Great Places to Work" list during this period.

In a related case, Accenture cut 600 support staff in June 2001 but for some staff the company instituted partially paid sabbaticals where the firm paid 20 percent of salary and all benefits and employees could keep laptops, an office phone number and e-mail. Roughly 1,000 workers took this option (Cascio, 2002).

Many universities this year are offering some staff "early retirement” incentives. In March 2009, Cornell University offered non-faculty staff who are were age 55 or older and worked for the University for at least ten years, one year's salary plus an additional 30 percent of a year pension contribution to retire by June. More than 400 people took the early-retirement option and left the university by June 2009.

Some, including Gordon (1996) have argued for "substituting compensatory time as an alternative to time-and-a-half for overtime - meaning that workers would be able to work less some other day if they worked extra hours today" (p. 247).

Oklander (2003) is an interesting case study of a company called Dynabil Industries which, in 2001 had 130 employees. After an "all hands meeting” called by the General Manager to discuss business performance and projection, all 130 employees filled out a questionnaire that asked them "how

\footnotetext{
${ }^{7}$ Charness and Levine (2000) find that people rate layoffs as "more fair" if the CEO voluntarily "shared the pain." They also find that people view layoffs due to "reduced demand" more fair than those due to "employee suggestions". They suggested that "companies should not punish employees for their efforts". (p. 381).
} 
many days per quarter they could absent themselves from work without pay, and to do so - or not do so completely voluntarily.” (Oaklander, 2003, p 7). They were further told their responses were nonbinding. About one-third said they could not sacrifice a day. In one of the 12 blue collar units, everyone volunteered. The fraction who did not volunteer varied from 16 percent to 75 percent by unit. Ten percent of women and 24 percent of men were willing to take more than ten days off. In all, 81 workers agreed to participate and a layoff was averted. It is not at all clear whether this could work elsewhere or whether it would work again in the same organization at some other time.

For some 60 years, Lincoln Electric has maintained a policy of guaranteed continuous employment - no permanent U.S. employee has been laid off for "lack of work." For Lincoln Electric, employee layoffs aren't just a last resort, the option isn't even put on the table for discussion. Instead, merit-based bonus pay, mandatory hours-reductions, and nimble project assignment are all among the tools that Lincoln Electric's leadership draws on when it needs to respond to business cycles turning south. (See Koller, 2010)

Even companies with long-histories of "no layoff" policies have faced job loss ${ }^{8}$. An anecdote may show that it is possible to see how quickly companies turn from a strong "no layoff" or "shared sacrifice" mentality to one entirely different. One of us visited a high-tech company with roughly 1,000 workers in 2001 right after their first job loss. There were discussions of extraordinary anguish and difficulty - including the CEO crying while telling part of his workforce that they would have to go. He visited the headquarters of the same organization about six months later, when they were beginning a new round of layoffs. The senior staff had an entirely different view - and described the situation in stark, economic terms. They said that if the next round of cuts weren't made, the entire company would go under. The emotion in the job loss seemed to be almost entirely gone.

\footnotetext{
${ }^{8}$ See Tuna's (2008) article in the Wall Street Journal: "No-Layoff Policies Crumble".
} 


\section{Work-Sharing}

Work-sharing is an alternative to layoffs which merits detailed discussion. It can be thought of as the redistribution of labor hours among people with the goal of reducing involuntary unemployment. As an example, consider a firm where all workers earn the same salary. The firm falls on hard times and needs to reduce its payroll by twenty percent. One way to do this is to layoff twenty percent of its workforce. Under a work-sharing arrangement, however, the firm can instead cut the hours of every worker by twenty percent - e.g., by telling workers to stay home on Fridays. This way, no worker loses his or her job, and the firm does not have to incur the costs of the layoff and of hiring and training when demand increases.

Under this arrangement workers are losing money. Governments can supplement this lost income under programs known as short-time compensation (STC), under which workers receive a prorated amount of unemployment insurance benefits to cover the reduction in pay associated with lost hours. For example, Reid (1982) studies an experimental Canadian program put in place in 1977 which resulted in layoffs being avoided in twenty-four firms. Instead of laying off a portion of their workforce, these firms reduced the hours of all employees, and the experimental program allowed those workers to receive unemployment insurance benefits for the day or so each week which they were not working. Reid concludes that most workers favored the plan because they received, in the typical case, an extra day off per week at the cost of a five percent of their after-tax income ${ }^{9}$, and that employers favored the plan because they avoided the costs associated with layoffs.

These programs exist in seventeen U.S. states, though they are seldom used. MacCurdy, Pearce and Kihlthau (2004) point out, for example, that less than one percent of California companies with UI claims participated in a STC program. Among the reasons they suggest for the low take-up rate are that workers may not want STC since it "imposes reductions in pay that can be avoided by acquiring alternative full-time" employment. Such work-sharing unemployment insurance (WSUI) plans are

\footnotetext{
${ }^{9}$ Of course, the higher the maintained income, the more expensive the program per participant.
} 
relatively much more popular overseas, and can be found in Austria, Belgium, Canada, the Czech Republic, Denmark, Finland, France, Germany, Hungary, Ireland, Italy, Japan, Luxembourg, the Netherlands, New Zealand, Norway, Poland, Portugal, the Slovak Republic, Spain, Switzerland, and Turkey (Hijzen and Venn, 2011).

What is one possible explanation for the cross-country variance in the use of work-sharing? Van Audenrode (1994) builds an implicit contract model with unemployment insurance to study the relationship between short-time compensation and hours flexibility. He shows that short-time compensation has to be relatively more generous that traditional UI systems in order to get workers to accept variable hours. Studying ten OECD countries, the evidence supports his model. He finds that in countries with the most generous STC programs hours respond quickly to changes in the need for labor. He concludes that overall labor adjustments in these countries are as flexible as in the United States because hours adjustments compensate for firing restrictions. He suggests that the failure of STC programs in the United States and Canada is caused by the fact that these programs were insufficiently generous.

In the remainder of this section on work-sharing we will discuss three issues. The first is a general description of work-sharing plans. The second is the effect of work-sharing on employment. The third is the role of work-sharing in the 2008-2009 recession, with a detailed discussion of the features of current work-sharing programs in OECD countries.

\section{Varieties of Work-Sharing}

The goal of work-sharing from a social perspective is that it might be able to reduce the number of workers who are involuntarily unemployed. This goal can be pursued under a number of different work-sharing programs. Dreze, Persson, and Miller (1986) present a work-sharing taxonomy consisting of three parts: (1) trading jobs, (2) sharing jobs, and (3) trading hours for jobs.

Perhaps the most common form of trading jobs is early retirement plans. The United Kingdom introduced such a program in 1976, allowing older workers to leave their jobs early and to receive an 
allowance from the government until the age of normal retirement, provided that their employer replaces them with an unemployed worker. This program was considered to be quite successful. Belgium offered a similar program starting in the late 1970s, but required that the replacement worker be an unemployed person under the age of thirty. France offered a similar program around that time. Studying these and other early retirement programs, Dreze, Persson, and Miller (1986) offer two conclusions. The first is that the mandatory replacement provision is necessary to achieve job creation. The second is that these programs should be popular with older workers, provided that the rate of income replacement is high enough.

Dreze, Persson, and Miller (1986) examine early retirement on a part-time basis — progressive retirement — as a type of job sharing. In 1982, the United Kingdom introduced a policy where a worker could retire early on a half-time basis, with the other half of the worker's hours being picked up by an unemployed person. In 1983, the French adopted a similar program. Both programs were extremely unsuccessful. In the U.K., for example, after twelve months of operation the program covered only 578 jobs.

By trading hours for jobs, Dreze, Persson, and Miller (1986) mean a statutory decrease in the number of hours per week worked by workers, with the goal of increasing the number of employed persons. Belgium and France experimented with such policies in the late 1970s and early 1980s with little success. With the exception of firms operating on a continuous basis with multiple shifts, policies which decreased hours per week without mandatory new hiring did not lead to a short-run reduction in unemployment. The authors conclude that early retirement with mandatory replacement is the most promising short-run approach to work-sharing.

\section{Effect of Work-Sharing on Employment}

On the surface, it seems that the effect of work-sharing on employment would be unambiguous: work spread over more people would result in higher employment. But is this the case? 
The Canadian province of Quebec gradually decreased its statutory standard workweek for hourly-wage non-union workers from forty-four hours to forty hours over a period of three years starting in 1997. The goal of this policy change was to incentivize firms to hire more workers — prior to the policy change, a Quebec firm would have to start paying time-and-a-half at forty-five hours, but after the policy change time-and-a-half pay would begin at forty-one hours. Notably, the policy change did not include a requirement that Quebec firms increase the wages of current workers in order to compensate them for their lost hours. Skuterud (2007) studies the effects of this policy change, and finds that it was associated with a twenty percent reduction in weekly hours worked beyond forty. However, the policy did not lead to an increase in employment, either at the province or industry level.

Given this evidence, where does the intuition break down? Work-sharing will necessarily increase employment if the amount of work that needs to be done is fixed. But this assumes that the amount of work needed to be done is fixed. Hunt (1998) challenges this assumption. Suppose that, as Skuterud (2007) describes, a policy were enacted which reduced the standard hours per week of work. If this implies an increase in the marginal cost of production at the pre-policy-change level of output, then optimal output will fall, and with it the demand for labor. In addition, this will be reinforced by the substitution effect — firms will substitute away from the now-more-costly input, labor, and towards capital. Thus, both hours and employment could actually fall, much less rise, due to work-sharing. There is evidence that something like this happened in Germany. Beginning in 1985, West German unions began to reduce the standard workweek — the maximum number of hours per week which do not require overtime pay — in an effort to reduce the number of unemployed workers. Using industry-level data and cross-industry variation in standard hours reductions, Hunt (1999) finds that worksharing may have reduced employment in the period 1984-1994.

The goal of increasing employment is especially important during a recession. We now turn to the effects of work-sharing on employment in such a macroeconomic environment. 


\section{Work-Sharing and the 2008-2009 Downturn ${ }^{10}$}

Hijzen and Venn (2011) study the effect of short-time work schemes on employment and average hours of OECD countries during the 2008-2009 recession. They conclude that work-sharing prevented many workers from joining the ranks of the unemployed, particularly in Germany and Japan.

Twenty-two OECD countries either set up new short-time measures or adjusted existing measures in response to the recession. In Belgium, Turkey, Italy, Germany, and Japan - the OECD countries with the highest take-up — between three and six percent of all employees in 2009 participated in a short-time program. Across countries, the goods producing and construction sectors have the highest take-up rates at the end of the last decade, while financial, business, social, and personal services have the lowest. Most OECD countries had a work-sharing UI system in place prior to the recession - new programs were introduced in Poland, the Netherlands, Hungary, the Czech Republic, the Slovak Republic, Mexico, and New Zealand.

The main features of these programs are work-sharing requirements, eligibility requirements, conditionality requirements, and generosity. There is inter-country variation across all these dimensions.

Work-sharing requirements specify the range of hours reduction required for STC eligibility. Austria, Canada, Denmark, Finland, Germany, Hungary, Ireland, Korea, the Netherlands, Norway, the Slovak Republic, Spain, Switzerland, Turkey, and the United States all have a minimum permissible reduction in weekly working hours for short-time workers. The Slovak Republic's requirement is a mere four percent, while Denmark, Ireland, and Norway all require an hours reduction of forty percent. The majority of countries allow a maximum hours reduction of one-hundred percent - i.e., a temporary layoff.

Eligibility requirements set conditions on firms and workers. For example, of the twenty-four OECD countries studied by Hijzen and Venn (2011), every country except Denmark, Ireland, the Netherlands, and New Zealand requires that firms provide justification of economic need in order for their workers to receive short-time compensation. Explicit agreements between workers and firms are often

\footnotetext{
${ }^{10}$ This section is based on Hijzen and Venn (2011).
} 
required. Some countries require that the participating worker be eligible for standard unemployment insurance benefits. Conditionality requirements are relatively less common. Examples include compulsory training for the worker, firm commitments not to fire workers receiving short-time compensation, and job-search requirements for the worker.

A natural measure of the generosity of a work-sharing UI program is the ratio of the income a STC worker receives to his normal income. There is variance in this measure within countries due to the minimum and maximum hours reductions discussed previously. In France and Korea, a worker can receive one-hundred percent of her normal wage under STC. The lowest ratio is about 0.3 , and is found in Ireland. Apart from Ireland and Poland, this ratio is larger than 0.6 for all countries. Workers in eighteen countries can enjoy a ratio of over 0.9 , given a certain hours reduction.

It is interesting to compare within-country the ratio of UI income to normal income under STC and the same ratio under a standard UI program. In almost every country a worker receives more money under STC than the standard unemployment benefit. Portugal is the only country where the standard UI benefit exceeds the work-sharing benefit, but even there the UI benefit is only greater when hours have been reduced by more than fifty-five percent.

An additional component of generosity is the length of time a worker can receive short-time compensation. The median length of time across these countries is twelve months. Finland has no limit. As of 2009, Japan has the second longest duration, at twenty-eight months. Five countries have a maximum duration of two years. Eight countries have a maximum duration of less than ten months. The responsiveness of the maximum duration to the recession is often striking. Turkey, for example, more than tripled its maximum duration, from less than four months pre-recession to twelve in 2009. Most dramatically, Austria went from a maximum duration of three months to a maximum duration of twentyfour.

To identify the effect of short-time compensation, Hijzen and Venn (2011) employ a differencesin-differences estimation strategy, using variation in labor-adjustment patterns and in the intensity of use 
of STC across countries and time. They conclude that STC had an important impact on job preservation during the recession, particularly in Germany and Japan.

\section{What are the Effects of Job Loss on Workers?}

Given that job loss is so widespread, it is important to understand the effects of job loss on individuals and families. For public policy reasons, it is particularly important to understand the size of

the effects. If, post job loss, workers quickly find new jobs, have wages and benefits near the same level and have no longer-term negative effects on themselves or their families, then we might think differently about job loss than if there were ill effects from job loss. Uchitelle and Kleinfield (1996) and Uchitelle (2006) describe interesting and moving personal stories of those who have lost jobs. The rest of this section uses larger data sets (including administrative data) to describe effects on subsequent work and wages, and on happiness and health. The next sub-section begins with a description of the timing of job loss.

\section{Timing of Job Loss Announcements}

It is interesting to consider whether firms manipulate the timing of announcements to their advantage and whether the timing of announcements has changed over time. Figure 3 shows the distribution of job loss announcements by any firm ever in the Fortune 500 for each of the 38 years from 1970 - 2007. The number of job loss announcements tracks the unemployment rate quite closely, except for the first two years in the sample and, for some reason, for the five years around the year 2000. Note, that these are announcements, and are not weighted by the number of people in the announcement. Nevertheless, it is remarkable that the two series track each other so well.

Given that we know something about the frequency of job loss announcements over time, it is interesting to consider whether companies have an incentive to manipulate the timing of 
announcements $^{11}$. Yermack (1997) provides evidence that senior managers may manipulate the timing of the release of news in their companies for their own benefit. He argues they do this, in particular, to game stock options. In interviews with a set of 40 senior managers in companies, Hallock (2006) investigated whether there might be manipulation of the timing of announcements. It is surprising that so many admitted such manipulation of timing:

I've never been a part of something like that but I would assume there is potential to do it. I imagine you time it just right to drive the stock price. I think firms game options. Senior Manager, High Tech

Yes. There are discussions like that. Our quarterly earnings release and conversation with analysts is day $\mathrm{x}$ so the announcement is day $\mathrm{x}+1$.

Vice President, Agriculture

People see patterns of announcements depending on the timing [of options]. Senior Manager, Nondurable Goods Manufacturing

At the same time, there were other managers who found the idea of manipulating timing deplorable:

No gaming. [Layoffs] can be absolutely devastating. One woman was lying on my floor screaming and crying. Senior Manager, Nondurable Goods Manufacturing

You make them when you have to make them. There has to be a catalyst event. It is a human decision. It is hard. We cut [a large percentage] of employees ... It is deplorable to manipulate for short-term financial gain. CEO, Mining

It was interesting to see that some managers felt that they could be flexible in when they made layoff announcements. They mentioned that if the firm was having a terrible year that they could "take a bath" and let workers go before the end of the fiscal year. This was so they could begin the new year with a "clean slate".

Our fiscal year starts on $[\mathrm{X}]$ of each year. We may make sure that all employees are out for the end of the fiscal year so we can have everyone out and lower costs for the next year. Senior Manager, Durable Goods Manufacturing

\footnotetext{
${ }^{11}$ The discussion here follows Hallock (2006) closely. The quotes from managers, below, are directly from that source.
} 
Fiscal year? I don't know. This business of taking a one-time charge. In $[\mathrm{X}]$ or the first weeks of [Y]. You report 2000 results plus exceptional one-time charge for severance and then you go into next year clean.

Vice President, Durable Goods Manufacturing

A few managers noted that they did not want to let workers go near "the holidays".

No one wants to do it at Thanksgiving or Christmas. Senior Manager, High Tech

There is always a year-end crisis ... So take the charge at the end of the year to make next year get better. Is that appropriate to be laying people off around the holidays? Senior Manager, Nondurable Goods

Manufacturing

We didn't want to have layoffs in December for emotional reasons, not financial ... We don't want to lay people off at Christmas. That just [expletive deleted]. Senior Manager, High Tech

This leads one to consider whether the timing of announcements during the year varies over time. Figure 4 shows the distribution of when the announcements occurred during the year, by decade. The period from 1970 -1979 and the period from 2000 - 2007 are quite different in this regard. Notice that the figure for the 1970s has an "inverted U" shaped. That is, there is a spike in announcements early in the year and another run up in the final weeks of the year. The period from $2000-2007$, on the other had, appears "flatter". That is, announcements seem to be timed more evenly throughout the year. This is consistent with the idea that layoff announcements are potentially more routine now than they were in the past. Figure 5 shows the distribution of the day of the week the layoff announcements appeared in the Wall Street Journal, by decade. The period from 2000 - 2007 is strikingly different from the other periods in that the announcements are as likely to appear on any day of the week. This is in striking contrast to previous decades.

\section{Effects on Subsequent Work and Wages}

Important considerations when workers lose jobs are how quickly they find new ones and do the new jobs have similar compensation and benefits. A large body of literature documents large and longlasting negative effects of job loss on workers' subsequent employment and earnings. 
In the seminal paper on the issue of earnings losses after displacement, Jacobson, LaLonde and Sullivan (1993) use administrative data from Pennsylvania during 1974 - 1986 on workers' earnings histories with details about their companies to consider the magnitude and the time pattern of wages for displaced workers. The administrative data are a very large sample which allows the authors to apply techniques from the program evaluation literature. The authors find that high-tenured workers leaving "distressed" firms suffer long-term losses on the order of 25 percent of their wages. Interestingly they also find that, on average, wage losses begin before workers lose their jobs, depend on local labor market conditions and industries and are significant even in cases where workers find jobs in similar companies.

In a follow-up to Jacobson, LaLonde and Sullivan (1993), Couch and Placzek (2008) perform a very similar analysis for a different state (Connecticut) and for a more recent time period. While their results are somewhat similar, there are some interesting differences. While Jacobsen, LaLonde and Sullivan (1993) find long-term (six years post displacement) effects of 25 percent lower earnings, Counch and Placzek (2008) estimate effects of 13 percent to 15 percent. Couch and Placzek (2008) find immediate effects of about 33 percent and Jacobson, LaLonde and Sullivan (1993) estimate immediate effects on the order of 40 percent. Counch and Placzek (2008) argue that the larger effects estimated in Pennsylvania are due to the fact that there was a very high fraction of Unemployment Insurance recipients in Pennsylvania during the time of that study ${ }^{12}$.

A host of other papers estimate earnings losses following displacement using a variety of sources including the Displaced Workers Supplement (e.g. Topel, 1990, Farber, 1997, Carrington, 1993 and Neal, 1995), the Panel Study of Income Dynamics (PSID) (e.g. Ruhm, 1991 and Stevens, 1997), the Health and Retirement Study (HRS) (e.g. Couch, 1998 and Chan and Stevens, 2004), and the National Longitudinal Survey (NLSY) (e.g. Farlie and Kletzer, 2003). In general, these studies find smaller negative effects on wages post-displacement than administrative studies. Given the potential biases from survey data, this is an interesting finding. Von Wachter, Handwerker and Hildreth (2009) try to reconcile differences

\footnotetext{
${ }^{12}$ Eliason and Storrie (1996) study long-term effects of displacement in Sweden using linked employer-employee data. They find that workers in Sweden also suffer long term losses in the short and long (4 years) run.
} 
between the administrative and survey results using a unique match of the Displaced Worker Supplement (DWS $)^{13}$ and administrative records in California. When they use a common method to account for measurement error in survey wages that are correlated with demographics of workers, they find earnings estimates are similar across the two data sources.

Some authors have taken a different approach to considering effects of job loss on wages. Two examples are Stevens (1997) and Hanner (2005). Using the PSID, Stevens finds that much of the persistence in the effects of negative earnings losses post-displacement are due to additional job losses in the years following the initial displacement. Hanner (2005), examines the effects of job loss on the distribution of earnings using, among other methods, quantile regression. He finds that, in his sample, while mean earnings fall by 22 percent, the $5^{\text {th }}$ percentile of income falls 45 percent and a significant number of workers experience gains following displacement.

In a more recent paper, Von Wachter, Song and Manchester (2007) investigate very long effects of displacement during the early 1980s recession on earnings using administrative data from 1974 through 2004. They find that workers who permanently leave an employer between 1980 and 1995, for which they worked a long time, have very large and continuing earnings losses as many as 20 years later. They attribute the losses to reductions in employment and in pay for those who continue to work.

\section{Effects on Happiness and Health}

Independent of the issue of earnings losses following displacement is the important issue of the effects of job loss on health and happiness of those who are displaced form work. There is a rich literature in applied psychology on the effects of job loss on the "survivors" of layoffs ${ }^{14}$ that we will not cover in this paper. More recent work by economists (and others) is focusing on the effects of job loss on health, both physical and emotional, for displaced workers.

\footnotetext{
${ }^{13}$ Also see Kletzer (1989) for an interesting investigation of the role of previous job tenure on earnings after job loss.

${ }^{14}$ See, for example, Brockner (1992), Brockner, Greenberg, Brockner, Bortz, Davy and Carter (1986), Brockner, Grover, Reed, DeWitt and O'Malley (1987), Brockner, Konovsky, Cooper-Schneider, Folger, Martin and Bies (1994), Illes (1996), and Mishra and Spreitzer (1998). Muirhead (2002) makes the business case for educational training for displaced workers.
} 
Much of the work in the area finds the overall health of displaced workers may be substantially comporomised as a result of job loss. Two papers have alternative findings to this. With a provocative title, Ruhm (2000) asks “Are Recessions Good for Your Health?”. He concludes the paper by stating, among other things, "Surprisingly the answer appears to be yes." (p. 647). Primarily relying on fixedeffect models with U.S. states as the unit of observation, Ruhm (2000) finds that total mortality and eight of his ten sources of mortality move with the business cycle ${ }^{15}$. Another study finds no negative effects on stress following job-loss. Browning, Dano and Heinesen (2006) study men in Denmark from 1981 1999 and find no evidence that being displaced from a job is related to being hospitalized for a stress related disease.

Given the potential problems with using state-level data to consider these sorts of questions, Sullivan and Von Wachter $(2007,2009)$ consider similar issues and study the relationship between job loss, career outcomes and mortality for individuals using administrative data.

They match quarterly earnings and employment records to death certificates and find that job displacement leads to a 15 percent to 20 percent increase in death rates during the subsequent 20 years. They calculate that if this rate continued beyond the estimation period that this would translate into a loss in life expectancy for someone at age 40 of 1.5 years! They go on to suggest that "factors correlated with a decrease in mean earnings and a rise in the standard deviation of earnings have the potential to explain an important fraction of the effect of displacement on mortality." (Sullivan and von Wachter, 2007, p. 1.) Additonally, Catalano and Wilson (1994) use individual panel data and find an increase in depression following job loss.

The effects on workers, from loss of earnings, to potentially serious health outcomes are substantial. If outcomes for workers are negative, and there is significant evidence that they are, it is important to consider the potential effects on companies. This is the subject of the next section.

\footnotetext{
${ }^{15}$ Also see Martikainen, Maki and Jantti (2007) who study the relationship between unemployment and mortality for Finnish men. They find "no excess mortality ... among those who, at baseline, were employed at workplaces that had experienced reductions in employment." (p. 1070).
} 


\section{What are the Effects of Job Loss on Firms?}

Many authors carefully document trends in worker attachment and job loss (e.g. Farber 2008), the personal stories of displaced workers (e.g. Uchitelle, 2006) or the effects of job loss on workers subsequent outcomes including earnings (e.g. Jacobson, LaLonde and Sullivan, 1993) and health (e.g. Sullivan and Von Wachter, 2009). While these studies are critically important to understanding the effects of job loss on workers, a distinct literature has been building more recently that aims to consider the effects of job loss on firms. In the first instance, it would seem reasonable that firms let workers go because it is in the best interest of the firm (or the firm, obviously, would not have done it) ${ }^{16}$. However, what would we think if, upon further investigation, we found that job loss is bad for workers and their families and it is bad for firms? This section aims to investigate the effects of job loss on companies. The effects include the outcomes for CEOs, for short-run stock prices, for company stock prices and viability in the longer run, and for productivity. Most of the analysis is necessarily confined to publicly traded companies in the United States.

\section{The Effect of Mass Layoffs on CEO pay}

There is a massive literature on executive compensation in the United States that may have been driven, in part, by access to data. Much of this work is focused on the extremely important goal of determining the link between the pay of the company CEO and the performance of the firm (e.g. Murphy, 1985). The aim of this section is to consider another potential correlate of CEO pay - job loss. Starting in the middle of the 1990s, the popular press (Sloan, 1996) and some policy groups (Anderson and Cavanagh, 1994) became very interested in the relationship between job loss in companies and executive

\footnotetext{
${ }^{16}$ Note, however, that some have argued for a broader view of goals of corporations. Blair and Gomoroy (2008) recently wrote "In the rush to globalization, the United States has tossed aside a crucial principle that guided the economic prosperity of the twentieth century: corporate leaders have a responsibility to their country, their community, and their employees that goes beyond maximizing share value."
} 
compensation - do executives profit at the same time (or in the wake of) their employees losing their jobs?

Hallock (1998) investigates the relationship between the compensation of CEOs of companies and whether those companies lay off workers. The paper uses data form three main sources. First, is the CEO compensation data collected from Forbes Magazines annual CEO compensation issues ${ }^{17}$. Three measures of compensation examined in the paper are salary plus bonus, salary plus bonus plus other (including such measures as savings plan contributions and the value of memberships to clubs) and total compensation (the sum of salary, bonus, other and also the value of stock options exercised). The second data on company characteristics is obtained from Standard \& Poor's Compustat and from The University of Chicago's Center for Research in Security Prices (CRSP). Finally, information on layoffs is from Pro Quest's Newspaper Abstracts. Abstracts from the Wall Street Journal were searched for the words "layoff," "laid off," “downsize," "plant closing," or "downsizing". 3,470 abstracts were found from 1987 through 1995.

In order to determine whether there is a simple relationship between layoff announcements and CEO pay, Hallock (1998) plots the number of layoff announcements in the Wall Street Journal and median CEO total compensation against time and finds that both grow over the sample period. Since, as pointed out by Rosen (1992) and others, CEO pay is very strongly related to company size, Hallock (1998) also plots the fraction of companies announcing at least one layoff and the real median CEO total compensation against the size of the company, as measured by market value of equity (Figure 6). The smallest ten percent of companies are in market value of equity decile 1 , the next 10 percent of companies are in decile 2 all the way up to the largest 10 percent of companies in decile 10 . It is clear from the figure that larger companies pay more and are more likely to announce a layoff in a given year.

A more formal analysis of layoffs and CEO compensation reveals that the apparent relationship may be nothing more than a mere statistical association. Table 2 shows the results of regressing the log of

\footnotetext{
${ }^{17}$ The reporting on CEO compensation is more detailed now than it was when this paper was published. There were major changes in how executive compensation is reported in 1992 and again in 2006.
} 
CEO total compensation ${ }^{18}$ on whether the company had a layoff in the previous year. The results of this regression appear in column (1) of Table 2. The coefficient on lagged layoff is 0.378 (translating into a percentage gain of roughly 46 percent), and it is highly statistically significant. This is a large effect, and taken at face value suggests that the pay premium to CEOs for making large layoffs is quite high. However, taking into account the importance of firm size (as evidenced by Figure 6) and other firmspecific characteristics, column (2) repeats the specification of column (1) with additional controls: lagged log market value of equity, lagged one year stock return, age of the CEO and its square, seniority of the CEO and its square, and yearly indicator variables. The coefficient on lagged layoff declines substantially to 0.134 but is still statistically significantly different from zero. Finally, in a specification controlling for individual firm effects (column 3), the coefficient on lagged layoff is negative and not statistically significantly different from zero. So, once firm-specific effects are controlled for, the CEO pay premium for laying off workers disappears. Note, however, that many CEOs hold many times their annual income in stock and stock options in their firms (Hallock and Torok, 2008). Therefore, in order to continue this investigation, it is sensible to consider the relationship between job loss announcements and stock prices.

\section{Mass layoffs and Profitability or Value in the Very Short Run}

There are many reports in the popular press of large layoffs at firms in the U.S. and around the world. There is also a great deal of discussion about the potential effects of these layoffs on companies executing layoffs. Some argue that the layoffs are necessary to maintain the financial health of the company. A host of studies linking job loss announcements to short-term stock prices have been written in the past few decades ${ }^{19}$. Following on early work (Farber and Hallock, 2009) that used data on the stock price reaction to layoffs announcements for any firm ever in the Fortune 500 from 1970 - 1999, here we report information on the stock price reaction to layoff announcements for any firm ever in the Fortune

\footnotetext{
${ }^{18}$ The results do not differ significantly if another form of compensation is considered instead.

${ }^{19}$ See, for example, Farber and Hallock (2009), Abowd, Milkovich and Hannon (1990), Blackwell, Marr and Spivey (1990), Caves and Kreps (1993), Gombola and Testsekos (1992), Gunderson, Verma and Verma (1997), Hallock (1998), Kalra, Henderson and Walker (1994) and Ursel and Armstrong-Stassen (1995).
} 
500 any year during the 38 year period from 1970 - 2007. (Refer back to Figure 3 for the distribution of the number of these announcements each year during the period.

The sample frame for this paper is every company that was ever in the Fortune 500 from 1970 through the end of 2007. For example, if a firm only joined the Fortune 500 in 1985, data were collected not only for 1985 but for every year in which the company was publicly traded. The Wall Street Journal Index was read for each company to locate any record of a job loss of any kind in any of these companies. After that, the complete article for each layoff event was then read $^{20}$. This yields a sample of 5,353 unique job loss announcements made by Fortune 500 firms during the 28 years from 1970 - 2007. (Refer back to Figure 3 for the distribution of the number of these announcements each year during the period).

In order to calculate the short-term stock price reaction to layoff announcements a simple event study method is used (see, for example, MacKinlay, 1997). We assume that the market became aware of the job loss announcement very near to the time of the printing in the Wall Street Journal.

We calculate cumulative average excess returns using value-weighted return data from the Center for Research in Security Prices (CRSP) at the University of Chicago. Let $t$ index time in trading days and let $\mathrm{i}$ index the companies. In the first-stage $\mathrm{R}_{\mathrm{it}}$, the daily stock return for the company, is regressed on $\mathrm{R}_{\mathrm{mt}}$, the value-weighted return for the market. This regression is run for some period in the past ${ }^{21}$ :

$$
\mathrm{R}_{\mathrm{it}}=\alpha_{\mathrm{i}}+\beta_{\mathrm{i}} \mathrm{R}_{\mathrm{mt}}+\eta_{\mathrm{it}}
$$

Next, for days around the event, the daily abnormal (or excess) returns can be calculated as follows:

$$
\mathrm{ER}_{\mathrm{it}}=\mathrm{R}_{\mathrm{it}}-\left(\hat{\alpha}_{\mathrm{i}}+\hat{\beta}_{\mathrm{i}} \mathrm{R}_{\mathrm{mt}}\right)
$$

where $\hat{\alpha}_{i}$ and $\hat{\beta}_{i}$ are estimated in the earlier equation. One can think of the excess return, ER, as the part of the movement in the stock return of company $i$ that is not correlated with overall market movement in stock returns and presumably reflects unexpected firm-specific factors.

\footnotetext{
${ }^{20}$ See Farber and Hallock (2009) page 2 for more details on how the data were constructed for the earlier period. The same structure was used to collect the data reported on here.

${ }^{21}$ The period from 60 days before to 30 days before the event is used. Various changes to this interval have no noticeable affect on the results.
} 
Excess returns can be calculated for many days around the "event window". In this paper, all calculations are based on a 3-day window (the day before, the day of, and the day after the event) ${ }^{22}$. Figure 7 displays the average cumulative excess returns over a three-day window for each of the 38 years from 1970 - 2007. It is clear from the figure that the share price reaction to job loss announcements was negative in the 1970s and seems to have flattened out by the middle to end of this decade.

One might ask whether the stock price reactions reported in Figure 7 may have been influenced by "other" news in the companies. For example, perhaps earnings were announced on the same day as the layoff. In order to isolate the effect of layoff announcements, the second line in Figure 7 repeats the analysis after removing any announcement that is within 30 days of another layoff, earnings announcement, stock split announcement or dividend announcement for the same company. It is clear from the figure that this does not markedly alter the main findings.

In addition to considering the average effect of job loss announcements on stock prices, one might also want to consider the distributional consequences on stock prices. Figure 8 is an attempt to investigate this issue. This figure reports the distribution of the returns by decade for the years 19701979, 1980-1989, 1990-1999 and 2000-2007. The figure shows a wide diversity in the returns by decade, with no marked differences in the spread of the distribution over time ${ }^{23}$.

Regression analysis shows that the stock price reaction to job loss announcements has, indeed, changed over time (Table 3). The table reports the results from regressions of the three-day cumulative excess returns on indicators for decade (the excluded decade is 1970 - 1979) and "reasons" for the layoffs (the reasons reported earlier are condensed into five categories: reorganization, plant closing, demand slump, cost and other (the excluded category is "missing reason"). From column (1), one can see that the excess returns in the 1970s (the constant term since the 1970s are the excluded category) were -0.654 percent. The returns in the 1980s were higher (less negative), the returns from the 1990s still higher and

\footnotetext{
${ }^{22}$ Changes to this window length have no material affect on the results.

${ }^{23}$ One might think that one reason for the shift toward zero in the stock price returns to job loss over time are due $\mathrm{t}$ the fact that news is no longer "newsworthy". Hallock and Mashayekhi (2006) investigate the share price reaction to a variety of corporate news announcements. They do not find evidence that is consistent with the "news is no longer newsworthy" hypotheses.
} 
the returns in the 2000s not statistically significant from those in the 1970s. Furthermore, changes in the mix of reasons for job loss announcements over time are not the explanation for the change in the returns to job loss announcement over time (column 2). The final columns of Table 3 report the results for each decade separately. Of note is the fact that the stock price reaction to job loss announcements for the "reorganization," "cost", and "other" reasons are strongly positively significant. Farber and Hallock (2009) explore many other reasons for the change in the stock price reaction to job loss announcements for an earlier period (that does not include data after 1999) and find that reasons, industry changes, type of worker (e.g. salaried versus not) do not explain the kinds of changes seen in Figure 7.

\section{Mass Layoffs, Productivity, Profitability and Value in the Longer Run}

Perhaps more important than considering the effects of job loss on the short-term stock price reaction of firms is to consider the long-term effects of lob loss on company viability and profitability ${ }^{24}$. The problem, of course, is that this is a much more difficult question to answer ${ }^{25}$. We can imagine that firms would not reduce headcount if it were not in the best interests of the company. However, increasing the time period over which we can study the "long-term" effects, also increases the probability that some confounding effects will be introduced into the analysis.

A classic example of a study of the longer-term effects of downsizing on corporate value is Dial and Murphy (1995). The authors describe an extraordinary change at General Dynamics that began in 1991. The company hired a new management team and committed to a strategy of creating shareholder value in the face of a potentially serious fall for demand for defense-related products. They also specifically tied compensation of senior managers to the creation of shareholder wealth ${ }^{26}$. The senior

\footnotetext{
${ }^{24}$ One possibility would be to do a longer-run event study of job loss announcements on abnormal returns such as how Desai and Jain's (1999) analysis of spinoffs.

${ }^{25}$ Brown, Haltiwanger and Lane (2006) discuss churning, workforce quality and firm productivity from a more macro perspective.

${ }^{26}$ The authors note that "Laying off employees and leaving communities is personally painful for managers (particularly those with long company tenures). It is relatively easy to provide incentives for growth: Managers intrinsically enjoy opening new plants, hiring new workers, and announcing new investment programs. In contrast, few managers enjoy downsizing: it's simply less fun than growing." (p. 266).
} 
managers began a strategy of extraordinary downsizing and restructuring which lead to sizeable compensation to the managers. Total employment at General Dynamics when the new CEO, William Anders, was hired in 1991 was 98,150. Total employment at General Dynamics at the end of 1993 was 26,800. During that same time period, executives at General Dynamics were rewarded and shareholders had gained a return of 553\%. Clearly there was more going on at General Dynamics than simply a new compensation package for managers and layoffs. Nevertheless, this is an extremely interesting case study. The CEO, Anders, had the following to say regarding whether resources from shareholders should have been used to help retrain workers who lost their jobs: "I do not see that we have a special obligation to our employees. This is an issue of excess human capacity that had to leave the defense industry. We trained our people to have specific skills and paid for that training. Then we paid them for their skills". (Dial and Murphy, 1995, p. 303).

Firms presumably downsize because they believe that downsizing will lead to better performance. An important measure of performance is productivity. If laid-off workers contributed relatively little to productivity, then we would expect productivity to rise after a layoff. It is reasonable to think that this is also the expectation of firms which choose to downsize. Is this happening?

Using plant-level data from the Longitudinal Research Database (LRD), Baily, Bartlesman, and Haltiwanger (1994) study productivity growth in the U.S. manufacturing sector during the 1980s, a period marked by extensive downsizing. They find, "in contrast to the conventional wisdom," "that plants that increased employment as well as productivity contribute almost as much to overall productivity growth in the 1980 s as the plants that increased productivity at the expense of employment" (emphasis added). Using the same methodology as Baily, Bartlesman, and Haltiwanger (1994) applied to the U.K. Annual Census of Production (ACOP) to study the U.K.'s motor vehicle manufacturing sector, Collins and Harris (1999) find that "successful" downsizers — firms which decreased employment and increased productivity — had higher productivity growth, but that firms which were "unsuccessful" downsizers — firms which decreased employment and productivity — had very low relative productivity growth. 
An alternative way to investigate the relationship between downsizing and productivity is to study the effects of employment protection. If firms want to downsize but are unable to do so due to legal and regulatory constraints, then we might expect firm performance to be hurt as consequence of the presence and enaction of employment protection.

Autor, Kerr, and Kugler (2007) use variation in the cost of dismissing employees brought on by the adoption of wrongful discharge protection by U.S. state courts from the late 1970s through the early 1990s to study the relationship between employment protection and productivity. Using establishmentlevel data from the U.S. Census Bureau, they find that wrongful discharge protection led to a reduction in employment flows and that the short-run rise in adjustment costs led to a decrease in total factor productivity. Bassanini, Nunziata, and Venn (2009) confirm this basic finding by studying the impact of job protection legislation on industry-specific productivity growth, employing a differences-in-differences strategy using panel data from eleven OECD countries. They find that layoff restrictions reduce productivity growth in industries where such restrictions are more likely to be binding.

A possible channel through which employment protection could decrease productivity is through the effort of "survivors" - those employees who remained employed by the firm after the firm downsized. Ichino and Riphahn (2005) study the effect of employment protection on a particular form of worker effort: worker absenteeism. They use weekly observations for male and female workers hired for white-collar jobs by a large Italian bank in the mid-1990s. For the first twelve weeks of employment, these workers are on probation; after twelve weeks the workers enjoy employment protection. The average numbers of days absent from work per week more than triples for men and shows a sizable increase for women after employment protection kicks in.

Joel Brockner and coauthors have extensively studied the effects of downsizing on survivors' effort, with mixed finding. Studying the effect of layoffs on survivors using a laboratory experiment, Brockner et al (1986) find evidence in support of "positive inequity theory" — the idea that by surviving a layoff, a worker will perceive her "outcome-to-input ratio" to be larger than her laid-off coworkers, will experience guilt, and will consequently increase her work effort. Likewise, Brockner et al (1993), using 
evidence from both the lab and the field, find that the work effort of survivors is increasing in the perceived threat of a future layoff.

Brockner et al (1992) argues that the change in work effort of survivors brought on by a layoff is driven by perceptions about job insecurity. Using survey data of employees of a national retail chain, they find that the pre- to post-layoff change in reported work effort follows an inverted U pattern over job insecurity — if survivors feel either very secure or very insecure about their employment probability then the change in work effort is relatively low, whereas if survivors feel moderately secure then the change in work effort is relatively large. They hypothesize that survivors who feel very secure may be complacent, that survivors who feel very insecure may feel helpless, and that workers who feel moderately secure may feel empowered to affect their outcome.

An interesting example of studying the longer-term effects of job loss is Cappelli (2000) who examines downsizings. He specifically defines "downsizing as reductions in jobs driven by the desire to improve operating efficiencies" and distinguishes that from "layoffs typically associated with shortfalls in demand." Cappelli uses data from the National Center on the Educational Quality of the Workforce (EQW) of the United States Census Bureau, which is an establishment-level survey of employment practices. He considers the relationship between downsizing and several outcomes including sales per worker, labor costs per worker, or labor costs as a percentage of total costs. The results do not all point to the same conclusion and the issues are, obviously, difficult. Unfortunately, the study did not include a measure of accounting profit or organization value, in the data. Nevertheless, one of Cappelli's interesting conclusions is that "At least in the mid-1990s, when these data were collected, job reduction decisions seem not to have been dominated by factors associated with shortfalls in demand. Whether this situation represents something distinct about that period - one of economic expansion when the level of excess capacity in establishments may have been too small to drive job cuts - or something more fundamental is a question for further research". (p. 511). 
One study that specifically measures the relationship between employment change and firm performance in the longer-run is Cascio, Young and Morris $(1997)^{27}$. The authors use 5,479 instances of changes in employment and investigate the relationship between these employment changes and return on assets (their measure of profitability) and return on common stock. However, as opposed to much of the current discussion, this study examines the total employment change in a firm that is not limited to layoffs (i.e. some of the job loss could be voluntary on the part of the worker and, in addition, if one worker leaves and another takes her place this would be undetected). With these limitations in mind, the authors find that companies that just lowered employment performed no better than other companies. On the other hand, companies that downsized and "restructured assets ${ }^{28}$ " had both higher returns on assets and returns on stock than their industry competitors.

The data on employment change in Cascio, Young and Morris (1997) are from Standard \& Poor's CompuStat. Our understanding is that the employment data in CompuStat are missing for a reasonably large fraction of the observations. Further the employment data are not audited (like accounting data) ${ }^{29}$ so these results should be regarded with some caution.

\section{The Relationship between Mass Layoffs and CEO Turnover}

Another firm outcome that can be studied with respect to job loss is CEO turnover ${ }^{30}$. Are job loss announcements and CEO turnover in large companies positively or negatively related? Which comes first? Are some CEOs hired to lay people off? Billger and Hallock (2005) examine some of these issues using data over a 31-year period on job loss announcements and CEO turnover. They find that CEO turnover is significantly related to one or more job loss announcements the previous year. This relationship has also changed over the decades (with a stronger effect in 1970s than in later decades).

\footnotetext{
${ }^{27}$ Wayhan and Werner (2000) study the long-term impacts of job loss for a sample of companies who reduced employment in 1991 or 1992. They find that workforce reductions improve financial performance, and that the effect is stronger in the short-run.

${ }^{28}$ They define "asset downsizers" as companies where the decline in employment was more than 5 percent and the decline in plant and equipment exceeded the change in employment by more than 5 percent.

${ }^{29}$ See Hallock (1998) for more detail.

${ }^{30}$ Of course, CEO turnover can be voluntary. In much of the literature on CEOs, however, turnover is thought to be a negative outcome.
} 
They consider different types of layoff announcements separately. Layoffs that are associated with negative stock price reactions (i.e. the market thought they were a "bad" idea) are more likely to lead to CEO turnover than those associated with positive stock price reactions (i.e. the market thought they were a "good" idea), especially earlier in the sample.

\section{Concluding Comments}

Job loss is extremely difficult for individuals, families and organizations. This paper provides an overview of just some of the issues related to job loss including changes in stability of jobs over time in the United States, the issues of timing of job loss, reasons for job loss and alternatives, work-sharing and short-time compensation programs, the relationship between job loss and subsequent wages and health of workers, and the effects of job loss on companies. Our own opinion is that things have changed quite a bit in this area in recent years. Cappelli (2005) notes "For employees, economic downturns are now more catastrophic, because more workers are laid off more quickly with less chance of being rehired, while those who remain employed find their employment conditions worsening. But upturns are now more advantageous, as employers bid not only for entry-level help, as they have in the past, but also for experienced workers." (p. 110).

There are several findings about job loss and its effects on firms and workers in this paper. First, it is clear that there has been a marked change in stability of jobs in the United States. A decline in job stability alone does not necessarily mean bad news for workers. In fact, increased job change could be good for workers. However, additional evidence suggests that on average, this is not the case. Second, there appears to have been a shift in the types of layoffs that have occurred in the past forty years in the United States. For example, job loss specifically due to "deficient demand" seems to be less prevalent than in the past. Third, a host of evidence shows a significant and negative impact of job loss on workers, both in terms of employment and earnings, and in terms of health and happiness. Fourth, the very shortterm stock price reaction to job loss announcements has changed markedly over time and is now quite modest. The longer-term impacts of job loss on company performance are less clear and more work 
needs to be done in this area. But if companies are not markedly improved by shedding workers, why does it happen? Fifth, a look overseas reveals that many countries handle job loss in a very different way than the United States.

Finally, there have been many public policy proposals in and suggestions for improving the economy and dampening the effects of job loss. Evidence suggests that much more work needs to be done in this area and to form a scientific base for designing effective evidence-based policy.

Nevertheless, it is clear from the sub-set of the papers in the literature studied here that the nature of the worker-firm relationship has changed quite a bit in the last few generations - a change that has negatively impacted the lives of workers and produced modest, if any, benefits for firms.

Will things ever be the way they used to be? Will the next recession be different? Are things different now than they were just a few years ago — did the so-called Great Recession further change the relationship between firms and workers? Has the employment contract, in fact, changed in the past few generations? It seems that the balance of evidence suggests that the answer to this last question is yes. 


\section{References}

Abowd, John, Kevin McKinney and Lars Vilhuber "The Link Between Human Capital, Mass Layoffs, and Firm Deaths" in T. Dunne, J.B. Jensen and M.J. Roberts, eds., Producer Dynamics: New Evidence from Micro Data (Chicago: University of Chicago Press for the National Bureau of Economic Research, 2009), pp. 447-472.

Abowd, John, George Milkovich, and John Hannon, 1990, "The Effects of Human Resource Management Decisions on Shareholder Value," Industrial and Labor Relations Review, February, 43(3), 203s$36 s$.

Addison, John T., and McKinley L. Blackburn, 1994, “The Worker Adjustment and Retraining Notification Act,” Journal of Economic Perspectives, 8(1), Winter, 181-90.

Alvey, Susan and Stever Robbins, 2007, Dismissing an Employee, Harvard Business School Press.

Anderson, Sarah and John Cavanagh, 1994, Workers Lose, CEOs Win, Washington DC: Institute for Policy Studies.

Autor, David, 2003, "Outsourcing at Will: The Contribution of Unjust Dismissal Doctrine to the Growth of Employment Outsourcing," Journal of Labor Economics, 21(1), 1-42.

Autor, David H., William R. Kerr, and Adriana D. Kugler, "Does Employment Protection Reduce Productivity? Evidence From U.S. States," The Economic Journal, vol. 117, June 2007, pp. F189F217.

Baily, Martin, Eric Bartelsman and John Haltiwanger, "Downsizing and Productivity Growth: Myth or Reality?" Small Business Economics, 1994.

Baily, Martin Neil, Eric J. Bartelsman and John Haltiwanger, 1996, "Downsizing and Productivity Growth: Myth or Reality?" Small Business Economics, 8(4), 259-278.

Bassanini, Andrea, Luca Nunziata, and Danielle Venn, "Job protection legislation and productivity growth in OECD countries," Economic Policy, vol. 24, no. 58, April 2009, pp. 349-402.

Blackwell, David, M. Wayne Marr, and Michael F. Spivey, 1990, "Plant Closing Decisions and the Market Value of the Firm," Journal of Financial Economics, 26(2), 277-88.

Bewley, Truman F., 1999, "Layoffs," Chapter 13 in Truman Bewley Why Wages Don't Fall During a Recession, Harvard University Press, pp. 218-262.

Billger, Sherrilyn M., and Kevin F. Hallock, 2005, "Mass Layoffs and CEO Turnover," Industrial Relations, 44(3), July.

Blair, Margaret and Ralph Gomoroy, 2008, "Leadership is More than Profit," Huffington Post, September 5.

Brislin, Joseph A., 1990, The WARN Act: A Manager's Compliance Guide to Workforce Reductions, The Bureau of National Affairs. 
Brockner, Joel, Steven Grovner, Thomas Reed, and Rocki DeWitt, 1992, "Layoffs, Job Insecurity, and Survivors' Work Effort: Evidence of an Inverted-U Relationship," Academy of Management Journal, 35(2), 413-25.

Brockner, Joel, 1992, "Managing the Effects of Layoffs on Survivors," California Management Review, Winter, 34(2), 9-27.

Brockner, Joel, Jeff Greenberg, Audrey Brockner, Jenny Bortz, Jeanette Davy, and Carolyn Carter, 1986, "Layoffs, Equity Theory, and Work Performance: Further Evidence on the Impact of Survivor Guilt," Academy of Management Journal, 29(2), 373-384.

Brockner, Joel, Steven Grover, Michael N. O’Malley, Thomas F. Reed, Mary Ann Glynn, “Threat of Future Layoffs, Self-Esteem, and Survivors' Reactions: Evidence from the Laboratory and the Field," Strategic Management Journal, vol. 14, summer 1993, pp. 153-166.

Brockner, Joel, Steven Grover, Thomas F. Reed, Rocki Lee Dewitt, "Layoffs, Job Insecurity, and Survivors' Work Effort: Evidence of an Inverted-U Relationship," The Academy of Management Journal, vol. 35, no. 2, June 1992, pp. 413-425.

Brockner, Joel, Mary Konovsky, Rochelle Cooper-Schneider, Robert Folger, Christopher Martin, and Robert J. Bies, 1994, "Interactive Effects of Procedural Justice and Outcome Negativity on Victims and Survivors or Job Loss," Academy of Management Journal, 37(2), 397-409.

Brown, Clair, John Haltiwanger and Julia Lane, 2006, "Economic Turbulence: What Who, and How Much?" Chapter 2 in Clair Brown, John Haltiwanger, and Julia Lane, Economic Turbulence: Is A Volatile Economy Good for America?, University of Chicago Press, pp. 10-22.

Brown, Clair, John Haltiwanger and Julia Lane, 2006, "Firms, Their Workers, and Their Survival," Chapter 4 in Economic Turbulence: Is a Volatile Economy Good for America?, University of Chicago Press, pp. 39-59.

Browning, Martin, Anne Moller Dano, and Eskil Heinesen, 2006, "Job displacement and stress related health outcomes," Health Economics, Vo.15 pp. 1061 - 1075.

Burgard, Sarah, Jennie Brand, and James House, 2007, "Toward a Better Estimation of the Effect of Job Loss on Health," Journal of Health and Social Behavior, Vol. 48 No. 4 pp. 369-384.

Butcher, Kristin, and Kevin F. Hallock, 2005, "Bringing Together Policymakers, Researchers, and Practitioners to Discuss Job Loss,” Economic Perspectives, Federal Reserve Bank of Chicago, $2^{\text {nd }}$ Quarter, 2005.

Caplan, Gayle and Mary Teese, 1997, "The Unexpected Costs of Downsizing," Chapter 1 in Gayle Caplan and Mary Teese Survivors: How to Keep Your Best People on Board After Downsizing, Davies-Black, pp. 1-10.

Cappelli, Peter, 1992, "Examining Managerial Displacement," Academy of Management Journal, 35(1), 203-17. 
Cappelli, Peter, 2000, "Examining the Incidence of Downsizing and Its Effect on Establishment Performance," in David Neumark, Editor, On the Job: Is Long-Term Employment a Thing of the Past?, Russell Sage Foundation, New York, pp. 463-416.

Carrington, William J., 1993, "Wage Losses for Displaced Workers: Is it really the Firm that Matters?" Journal of Human Resources, 12(2), pp. 243-275.

Cascio, Wayne F., Clifford E. Young, and James R. Morris, 1997, "Financial Consequences of Employment Change Decisions in Major U.S. Corporations," Academy of Management Journal, 40(5), 1175-89.

Cascio, Wayne, 2002, "Responsible Restructuring - Alternative Strategies," Chapter 5 in Wayne Cascio Responsible Restructuring: Creative and Profitable Alternatives to Layoffs, Berrett-Koehler Publishers, Inc. San Francisco, 49-70.

Cascio, Wayne F., 2002, "Restructuring in Perspective," Chapter 1 in Wayne Cascio Responsible Restructuring: Creative and Profitable Alternatives to Layoffs, Berrett-Koehler Publishers, Inc. San Francisco, pp. 3-15.

Caves, Richard. E. and Matthew B. Kreps, 1993, "Fat: The Displacement of Nonproduction Workers from U.S. Manufacturing Industries," Brookings Papers on Economic Activity, Microeconomics, 2, 227-73.

Chan, Sewin and Ann Huff Stevens, 2001, "Job Loss and Employment Patterns of Older Workers," Journal of Labor Economics, Vol. 19(2), pp. 484-521.

Chan, Sewin and Ann Huff Stevens, 2004, "How Does Job Loss Affect the Timing of Retirement?" Contributions to Economic Analysis and Policy, 31(3).

Charness, Gary, and David I. Levine, 2000, "When Are Layoffs Acceptable? Evidence From a QuasiExperiment," Industrial and Labor Relations Review, 53(3), 381-400.

Collins, Alan and Richard I. D. Harris, "Downsizing and Productivity: The Case of UK Motor Vehicle Manufacturing 1974-1994," Managerial and Decision Economics, vol. 20, no. 5, August 1999, pp. 281-290.

Couch, Kenneth A., 1998, “Late Life Displacement,” The Gerentologist, 38(1), pp. 7 - 17.

Couch, Kenneth, and Dana W. Placzek, 2008, "The Earnings Loss of Displaced Workers Revisited," American Economic Review, forthcoming.

Davis, Steven J., John C. Haltiwanger and Scott Schuh, 1996, Job Creation and Destruction, MIT Press.

DeMuse, Kenneth D. and Mitcehll Lee Marks, Eds., 2003, Resizing the Organization: Managing Layoffs, Divestitures, and Closings. San Francisco, CA: Jossey-Bass.

Desai, Hemang, and Prem C. Jain, 1999, "Firm Performance and Focus: Long-Run Stock Market Performance Following Spinoffs," Journal of Financial Economics, 54, 75-101.

Dial, Jay, and Kevin J. Murphy, 1995, "Incentives, Downsizing, and Value Creation at General Dynamics," Journal of Financial Economics, 37(3), March, 261-314. 
Dreze, Jacques H., Torsten Persson, and Marcus Miller. "Work-Sharing: Some Theory and Recent European Expereince,” Economic Policy, vol. 1, no. 3, October 1986, pp. 561-619.

Elder, Tood, E., 2004, "Reemployment Patterns of Displaced Older Workers," paper presented at Federal Reserve Bank of Chicago Conference on Job Loss; Causes, Consequences and Policy Responses.

Eliason, Marcus and Donald Storrie, 2006, "Latent or Lasting Scars: Swedish Evidence on the Long-Term Effects of Job Displacement," Journal of Labor Economics, Vol. 24 No. 4, pp. 831856.

Fairlie, Robert W. and Lori G. Kletzer, 2003, “The Long-Term Costs of Job Displacement Among Young Workers," Industrial and Labor Relations Review, 56(4), pp. 682 - 698.

Farber, Henry S., 1997, “The Changing Face of Job Loss in the United States: 1982 - 1995,” Brookings Papers on Economic Activity: Microeconomics, pp. 55 - 142.

Farber, Henry S., 1999 "Alternative and Part-Time Employment as a Response to Job Loss," Journal of Labor Ecnomics, 17, October, pp. s142 - s169.

Farber, Henry S., 2003 "Job Loss in the United States, 1981-2001," Princeton University Industrial Relations Section Working Paper \#471, Princeton, NJ: Industrial Relations Section.

Farber, Henry S., 2005, "What Do We Know About Job Loss in the United States Evidence from the Displaced Workers Survey, 1984-2004," Federal Reserve Bank of Chicago Regional Review, pp. pp. $13-28$.

Farber, Henry S., 2007, "Is the Company Man an Anachronism? Trends in Long Term Employment in the U.S., 1973-2006, Princeton University Industrial Relations Section Working Paper \#518, September.

Farber, Henry S., 2008a, "Job Loss and the Decline in Job Security in the United States," forthcoming in Labor in the New Economy, Katherine Abraham, James Spletzer and Michael Harper, University of Chicago Press for NBER.

Farber, Henry S., 2008b, "Employment Insecurity: The Decline in Worker-Firm Attachment in the United States," Princeton University Industrial Relations Section Working Paper \#530, July.

Farber, Henry S. and Kevin F. Hallock, 2009, "The Changing Relationship Between Job Loss Announcements and Stock Prices: 1970-1999”, Labour Economics, 16(1), January, 1-11.

Farber, 2011, "Job Loss in the Great Recession: Historical Perspective from the Displaced Worker Survey, 1984-2010,” National Bureau of Economic Research Working Paper, '17040.

Freeman, Richard B. and Joel Rogers, 1999, What Workers Want. Ithaca, NY: Cornell University Press.

Godement, Franc, 1999, The Downsizing of Asia. London: Routledge. 
Gombola, Michael J. and George P. Tsetsekos, 1992, "Plant Closings for Financially Weak and Financially Strong Firms," Quarterly Journal of Business and Economics, 31(3), Summer, pp 6983.

Gordon, David, 1996, "Can We Take the High Road?," Chapter 9 in David Gordon, Fat and Mean: The Corporate Squeeze of Working Americans and the Myth of Managerial Downsizing, Free Press, 238-253.

Gunderson, Morley, Anil Verma and Savita Verma, 1997, "Impact of Layoff Announcements on the Market Value of the Firm," Relations Industrielles/Industrial Relations, Spring, 52(2), pp. 364381.

Hallock, Kevin F., 1998, "Layoffs, Top Executive Pay, and Firm Performance," The American Economic Review, 88(4), September, 711-723.

Hallock, Kevin F., 2006, "Layoffs in Large U.S. Firms from the Perspective of Senior Management," Research in Personnel and Human Resource Management, Volume 25, Elsevier, pp. 137-179.

Hallock, Kevin F, 2009, "Job Loss and The Fraying of the Implicit Employment Contract," Journal of Economic Perspectives, 23)4), Fall, 69-93.

Hallock, Kevin F., and Farzad Mashayekhi, 2006, "Are Formal Corporate News Announcements Still Newsworthy? Evidence from 30 Years of Data on Earnings, Splits, and Dividends," working paper Cornell University.

Hallock, Kevin F. and Judit Torok, 2008, Top Executive Compensation in 2008, New York: The Conference Board.

Hanner, Dan, 2005, "Changes in the Distribution of earnings Following a Job Displacement: An Applications of Quantile Regression in a Panel Data Setting," working paper, University of Illinois at Urbana-Campaign.

Hijzen, Alexander and Danielle Venn. "The Role of Short-Time Work Schemes during the 2008-09 Recession”, OECD Social, Employment and Migration Working Papers, no. 115, 2011. http://dx.doi.org/10.1787/5kgkd0bbwvxp-en

Hildreth, Andrew, Till von Wachter, and Elizabeth Weber Handwerker, 2008, "Estimating the 'True' Cost of Job Loss: Evidence using Matched Data from California 1991-2000,” working paper, Columbia University.

Hunt, Jennifer and Lawrence F. Katz. "Hours Reductions as Work-Sharing," Brookings Papers on Economic Activity, vol. 1998, no. 1, 1998, pp. 339-381.

Hunt, Jennifer. "Has Work-Sharing Worked in Germany?" Quarterly Journal of Economics, vol. 114, no. 1, February 1999, pp. 117-148.

Ichino, Andrea and Regina T. Riphahn, "The Effect of Employment Protection on Worker Effort: Absenteeism during and after Probation," Journal of the European Economic Association, vol. 3, no. 1, March 2005, pp. 120-143. 
Illes, Louise Moser, 1996, “The Announcement,” Chapter 2 in Louise Moser Illes Sizing Down: Chronicle f a Plant Closing, ILR Press, Cornell University Press, 5-17.

Illes, Louise Moser, 1996, "February: Moving to Anger and Denial," Chapter 4 in Sizing Down: Chronicle of a Plant Closing, ILR and Cornell University Press, pp. 18-28.

Jacobson, Louis. J., Robert J. LaLonde, and Daniel G. Sullivan, 1993, "Earnings Losses of Displaced Workers," American Economic Review, 83(4), 685-709.

Jacoby, Sanford, 1998, “Downsizing in the Past,” Challenge, May-June, 41(3), 100-12.

Kalra, Rajiv, Glenn V. Henderson Jr. and Michael C. Walker, 1994, "Share Price Reaction to PlantClosing Announcements,” Journal of Economics and Business, 46(5), December, pp. 381-395.

Kammeyer-Mueller, John, Hui Liao, and R. D.Avery, 2001, "Downsizing and Organizational Performance: A Review of the Literature from a Stakeholder Perspective," Research in Personnel and Human Resources Management, 20, 269-329.

Kletzer, Lori, 1989, "Returns to Seniority After a Permanent Job Loss," American Economic Review Vol. 79 No. 3 pp. 536-43.

Kollers, Frank, 2010, Spark: How Old-Fashioned Values Drive a Twenty-First-Century Corporation: Lessons from Lincoln Electric's Unique Guaranteed Employment Program, PublicAffairs ${ }^{\mathrm{TM}}$, a member of Perseus Books Group

Lester, Ricrad. A., 1948, Company Wage Policies: A Survey of Patterns and Experience. Princeton, NJ: Industrial Relations Section, Princeton University.

MacKinlay, A. Craig, 1997, "Event Studies in Economics and Finance," Journal of Economic Literature, 35(1), March, pp. 13-39.

MaCurdy, Thomas, James Pearce and Richard Kihlthau, 2004, "An Alternative to Layoffs: Work Sharing Unemployment Insurance,” California Policy Review, August, 1-11.

Marks, Mitchell Lee, 2003, Charging Back up Hill. San Francisco, CA: Jossey-Bass.

Martikainen, Pekka, Netta Mäki, and Markus Jäntti, 2007, “The Effects of Unemployment on Mortality following Workplace Downsizing and Workplace Closure: A Register-based Follow-up Study of Finnish Men and Women during Economic Boom and Recession," American Journal of Epidemiology Vol. 165 No. 9 pp. 1070 - 1075.

Mishra, Aneil K. Gretchen Spreitzer, 1998, "Explaining How Survivors Respond to Downsizing: The Roles of Trust, Empowerment, Justice, and Work Redesign," Academy of Management Review, 23(3), 567-588.

Muirhead, Sophia, 2002, "Compassionate Downsizing: Making the Business Case for Educational Training for Transitioned Employees," Executive Action No. 31, The Conference Board.

Murphy, Kevin J., 1985, "Corporate Performance and Managerial Remuneration: An Empirical Analysis," Journal of Accounting and Economics, 7(1-3), pp. 59-76. 
Neal, Derek, 1995, "Industry-Specific Human Capital: Evidence from Displaced Workers," Journal of Labor Economics, 13(4), pp. 653 - 677.

Neumark, David, Ed., 2000, On the Job: Is Long-Term Employment a Thing of the Past? New York: Russell Sage Foundation.

The New York Times, 1996, The Downsizing of America. New York: Times Books.

Oaklander, Harold, 2003, "Innovative Workforce Restructuring," Alliance for the Prevention of Unemployment (APU).

ProQuest, various years, Newspaper Abstracts, Ann Arbor, MI: UMI Research Collections.

Reid, Frank. "UI-Assisted Worksharing as an Alternative to Layoffs: The Canadian Experience," Industrial and Labor Relations Review, vol. 35, no. 3, April 1982, pp. 319-329.

Rosen, Sherwin, 1992, "Contracts and the Market for Executives," in Contract Economics, Lars Werin and Hans Wijkander, Eds, Oxford: Blackwell.

Ruhm, Christopher, 1991, “Are Workers Permanently Scarred by Job Displacements?' American Economic Review Vol. 81 No. 1 pp. 319-24.

Ruhm, Christopher, 2000, “Are Recessions Good for Your Health?” Quarterly Journal of Economics Vol. 115 No. 2 pp. 617-650.

Skuterud, Mikal. "Identifying the Potential of Work-Sharing as a Job-Creation Strategy," Journal of Labor Economics, vol. 25, no. 2, April 2007, pp. 265-287.

Stevens, Ann Huff, 1997, "Persistent Effects of Job Displacement: The Importance of Multiple Job Losses," Journal of Labor Economics, Vol. 15 No. 1 Part 1 pp. 165-188.

Sullivan, Daniel and Till von Wachter, 2007, "Mortality, Mass-Layoffs, and Career Outcomes: An Analysis using Administrative Data,” NBER Working Paper No. 13626.

Sullivan, Daniel and Till Von Wachter, 2009, "Job Displacement and Mortality: An Analysis using A dministrative Data," Quarterly Journal of Economics, forthcoming

Schuh, Scott, and Robert K. Triest, 2000, "The Role of Firms in Job Creation and Destruction in U.S. Manufacturing," New England Economic Review, March/April, 29-44.

Topel, Robert, 1990, "specific Capital and Unemployment: Measuring Costs and Consequences of Worker Displacement," Carnegie-Rochester Series on Public Policy, 33, pp. 181-214.

Tronti, Leonardo and Umberto Carabelli, 1999 "Introduction to Special Issue called Issues on the Management of Redundancies in Europe," Labour: Review of Labour Economics and Industrial Relations, 13(1), 3-39.

Tuna, Cari, 2008, “No-Layoff Policies Crumble,” Wall Street Journal, December 30, p. B2. 
Uchitelle, Louis and N.K. Kleinfield, "The Price of Job Loss," Chapter 1 in The New York Times, 1996, The Downsizing of America, Times Books, pp. 3-36.

Uchitelle, Louis, 2006, "The Shock, Part I," Chapter 4 in Louis Uchitelle The Disposable American: Layoffs and Their Consequences, Knopf, pp. 80-97.

Uchitelle, Louis, 2006, "The Shock, Part II," Chapter 5 in Louis Uchitelle The Disposable American: Layoffs and Their Consequences, Knopf, pp. 98-123.

Ursel, Nancy and Marjorie Armstrong-Stassen, 1995, “The Impact of Layoff Announcements on Shareholders," Relations Industrielles/Industrial Relations, 50(3), Summer, pp. 636-649.

Van Audenrode, Marc A., 1994, "Short-Time Compensation, Job Security, and Employment Contracts: Evidence from Selected OECD Countries," Journal of Political Economy, 102(1), 76-102.

von Wachter, Till, Jae Song, and Joyce Manchester, 2007, "Long-Term Earnings Losses due to Job Separation During the 1982 Recession: An Analysis Using Longitudinal Administrative Data from 1974 to 2004," working paper, Social Security Administration.

Wayhan Victor B. and Steve Werner, 2000, "The Impact of Workforce Reduction on Financial Performance: A Longitudinal Perspective,” Journal of Management, 26(2), pp. 341-363.

Yermack, David, 1997, "Good Timing: CEO Stock Option Awards and Company News Announcements," Journal of Finance, June, 52, 449-476. 
Figure 1a. Mean Job Tenure by Age and Year Cohort: Men

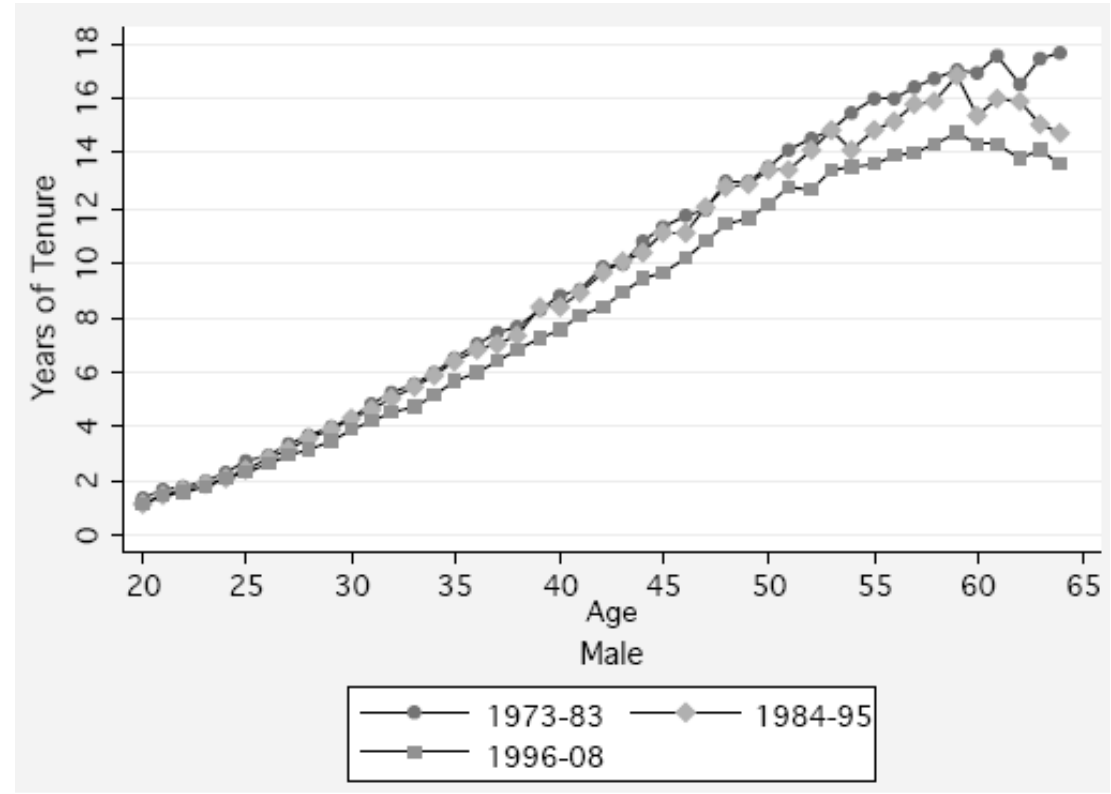

Figure 1b. Mean Job Tenure by Age and Year Cohort: Women

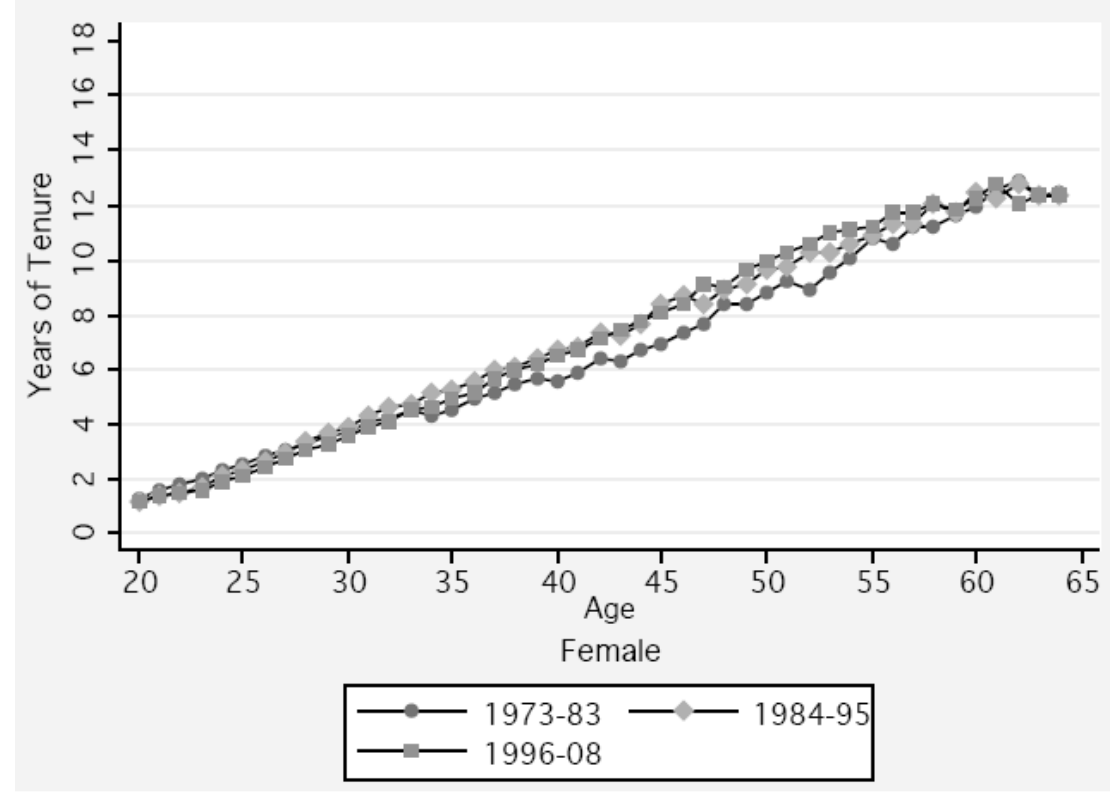

Source: Henry Farber using Displaced Workers Supplements 
Figure 2. Distribution of Stated Reasons for Announced Job Loss Over Time
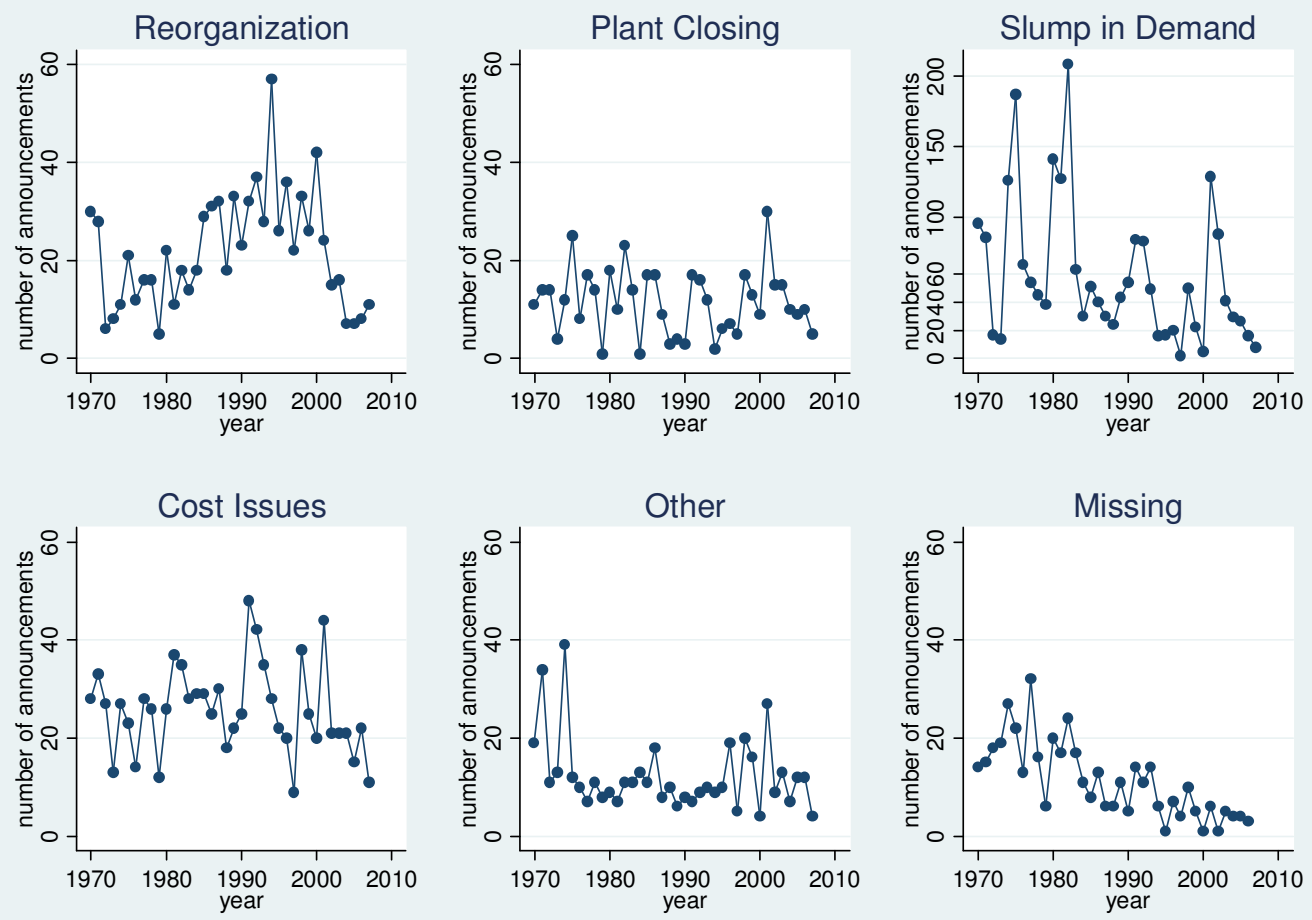

Categories are consolidated from the categories listed in Table 1. Categories are "Reorganization" (Reorganization, Restructuring and In-House Merger), "Plant Closing" (Leave Market and Plant Closing), "Slump in Demand" (Demand Slump, Excess Supply, Structural), "Cost Issues" (Cost Control, Posting Losses, Increase Earnings and Restore Profitability), "Other" (Increased Competition, Merger, Bankruptcy, Strike and Other), and "Missing". 
Figure 3. Number of Layoff Announcements and Unemployment Rate, by Year

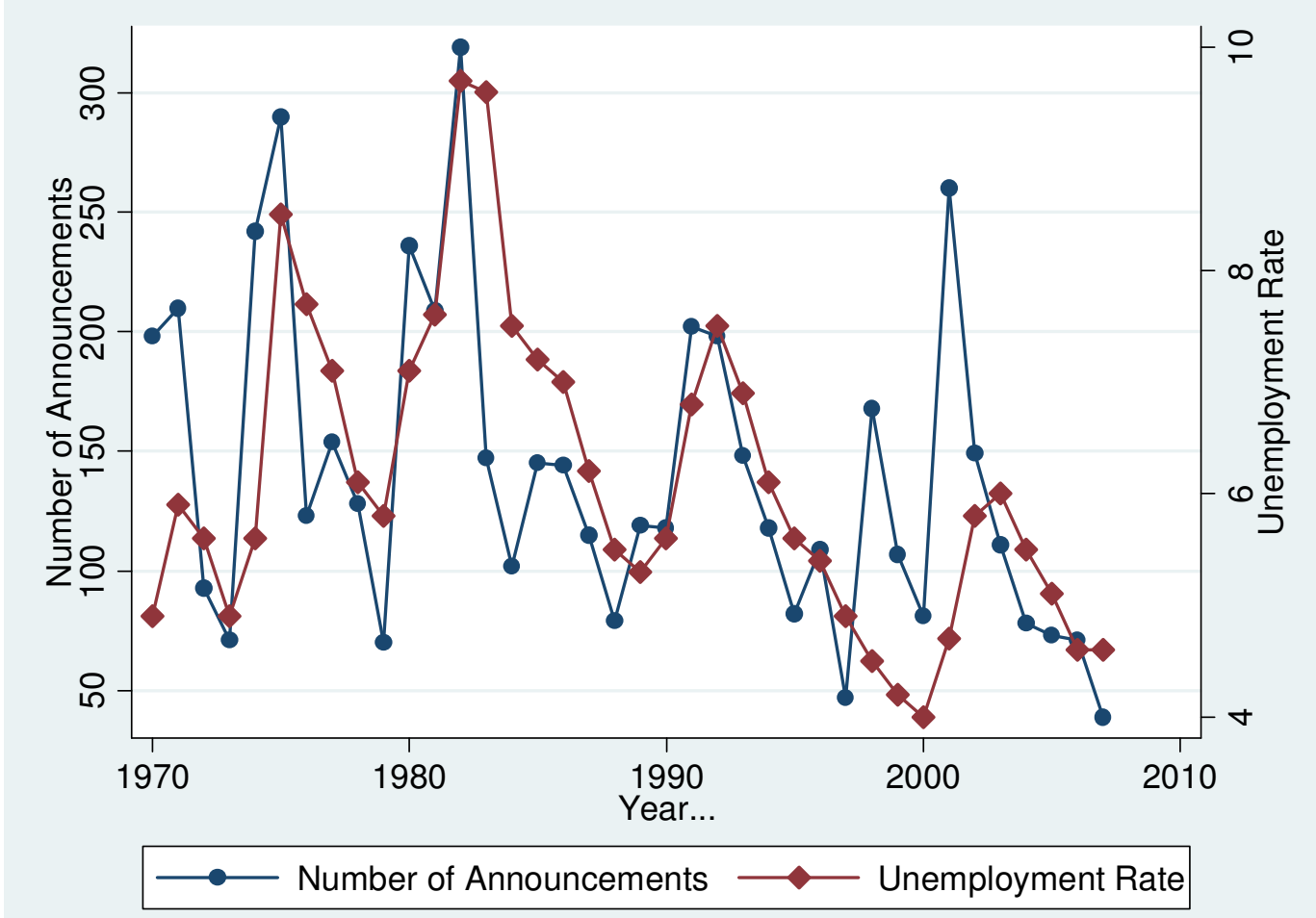

Source: Calculations by the authors using announcement information from the Wall Street Journal. 
Figure 4. Frequency of Announced Layoffs by Week in the Year
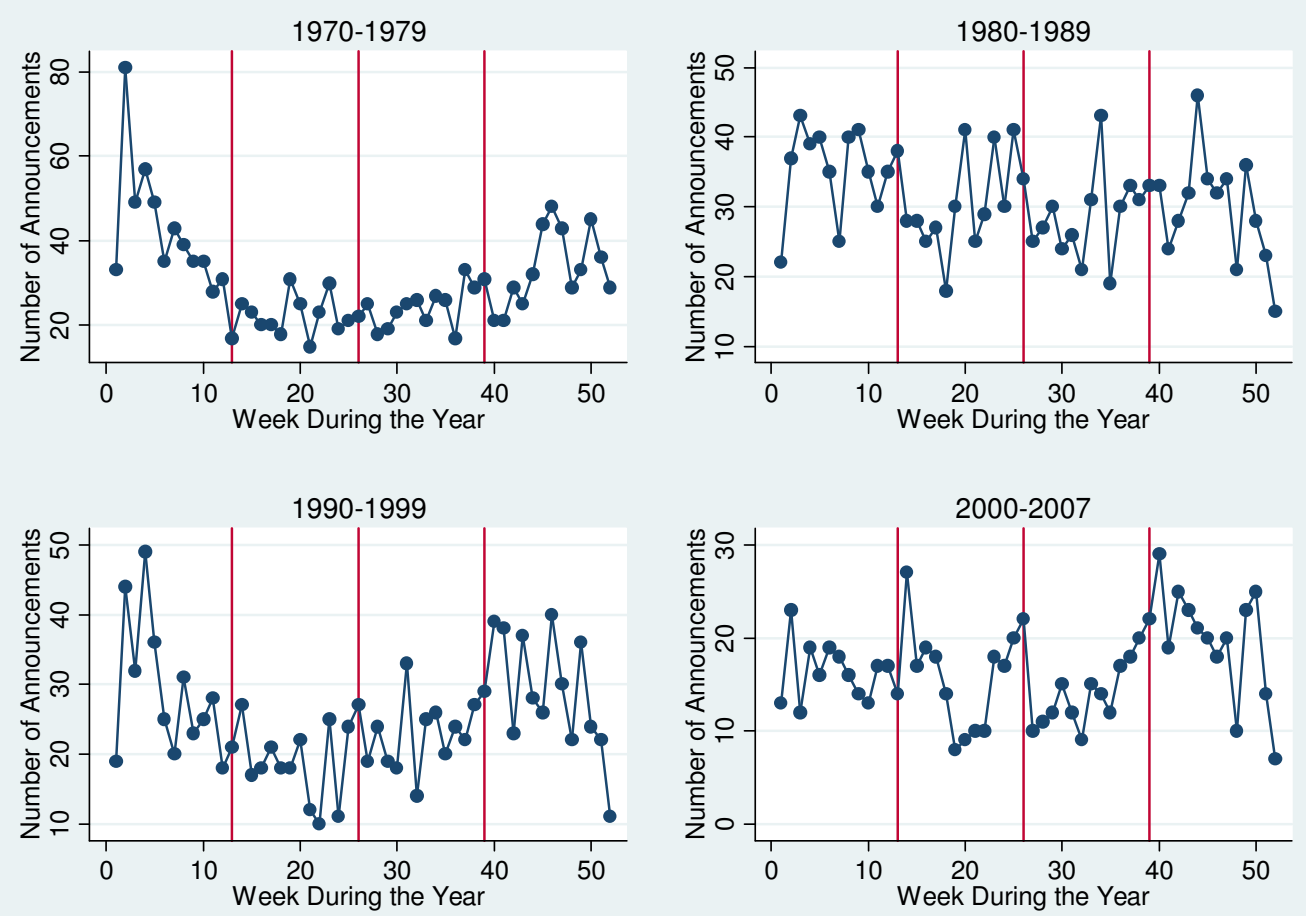

Source: Calculations by the authors using announcement information from the Wall Street Journal. 
Figure 5. Frequency of Job Loss Announcements by Day of Week they Appeared in the Wall Street Journal
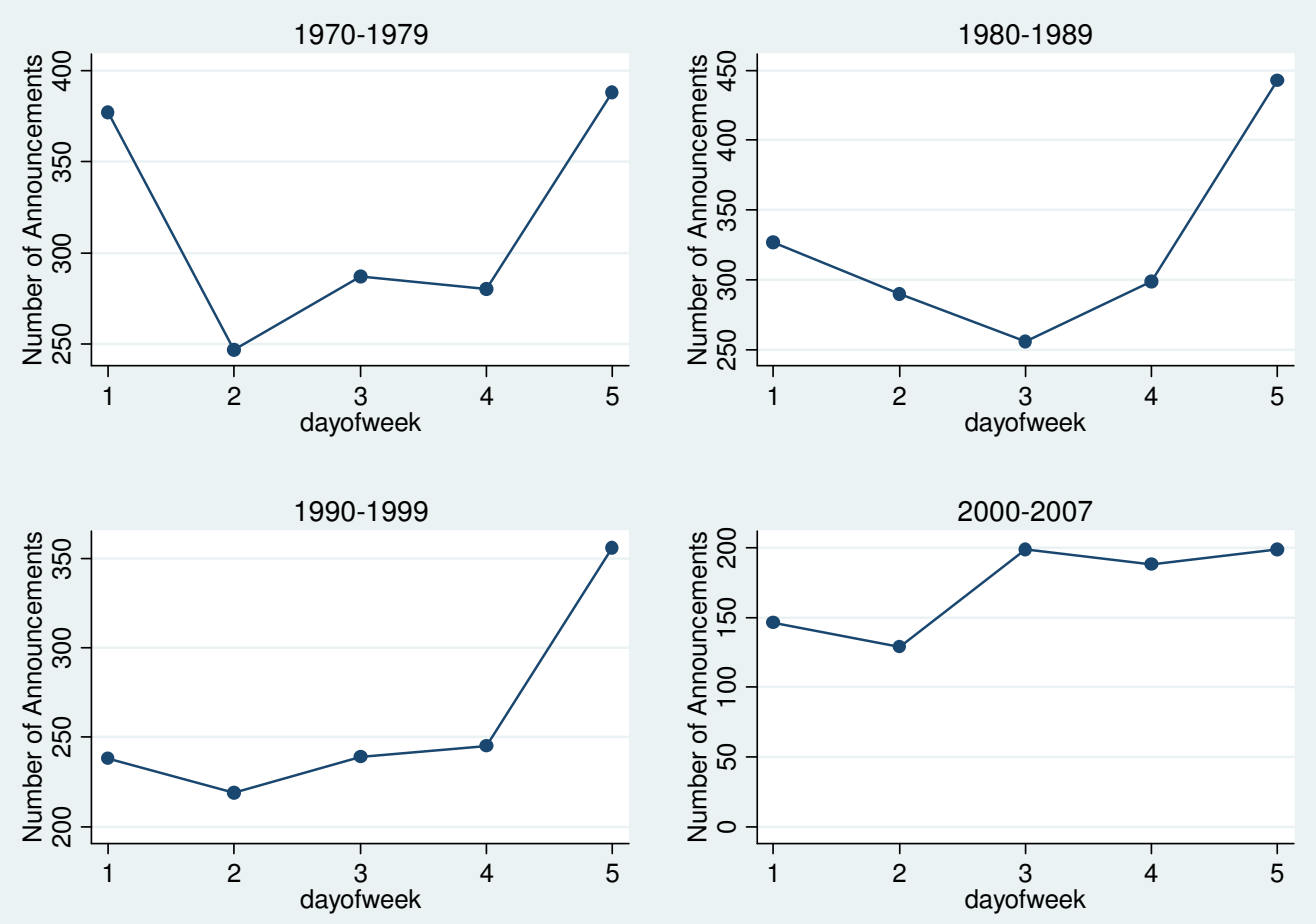

Source: Calculations by the authors using announcement information from the Wall Street Journal. 
Figure 6. Fraction of Firms Announcing at Least One Layoff and Median Total Compensation by Market Value of Equity Decile

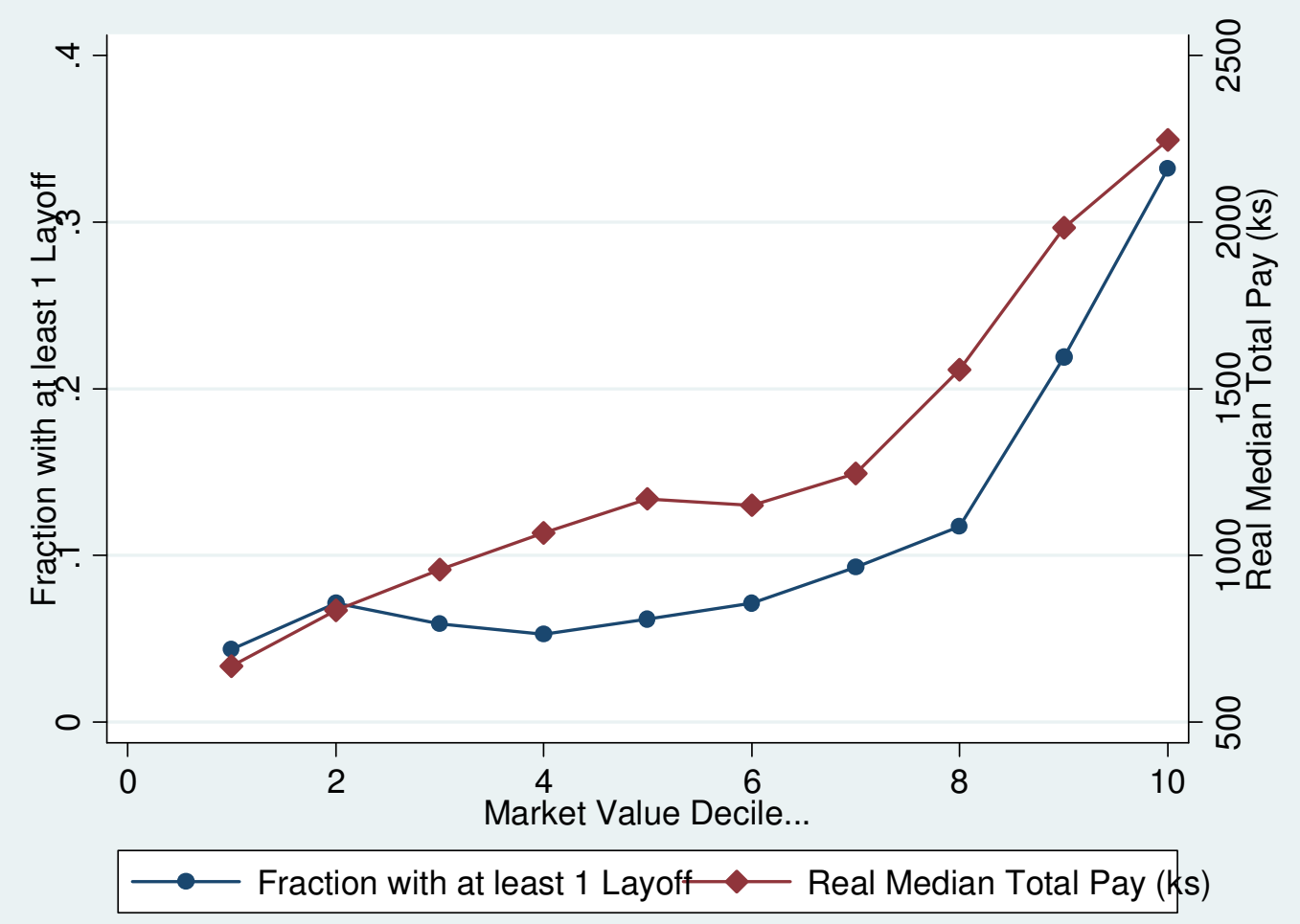

Source: Hallock (1998). 
Figure 7. Cumulative Average Excess Returns (One Day Before to One Day After the Layoff)

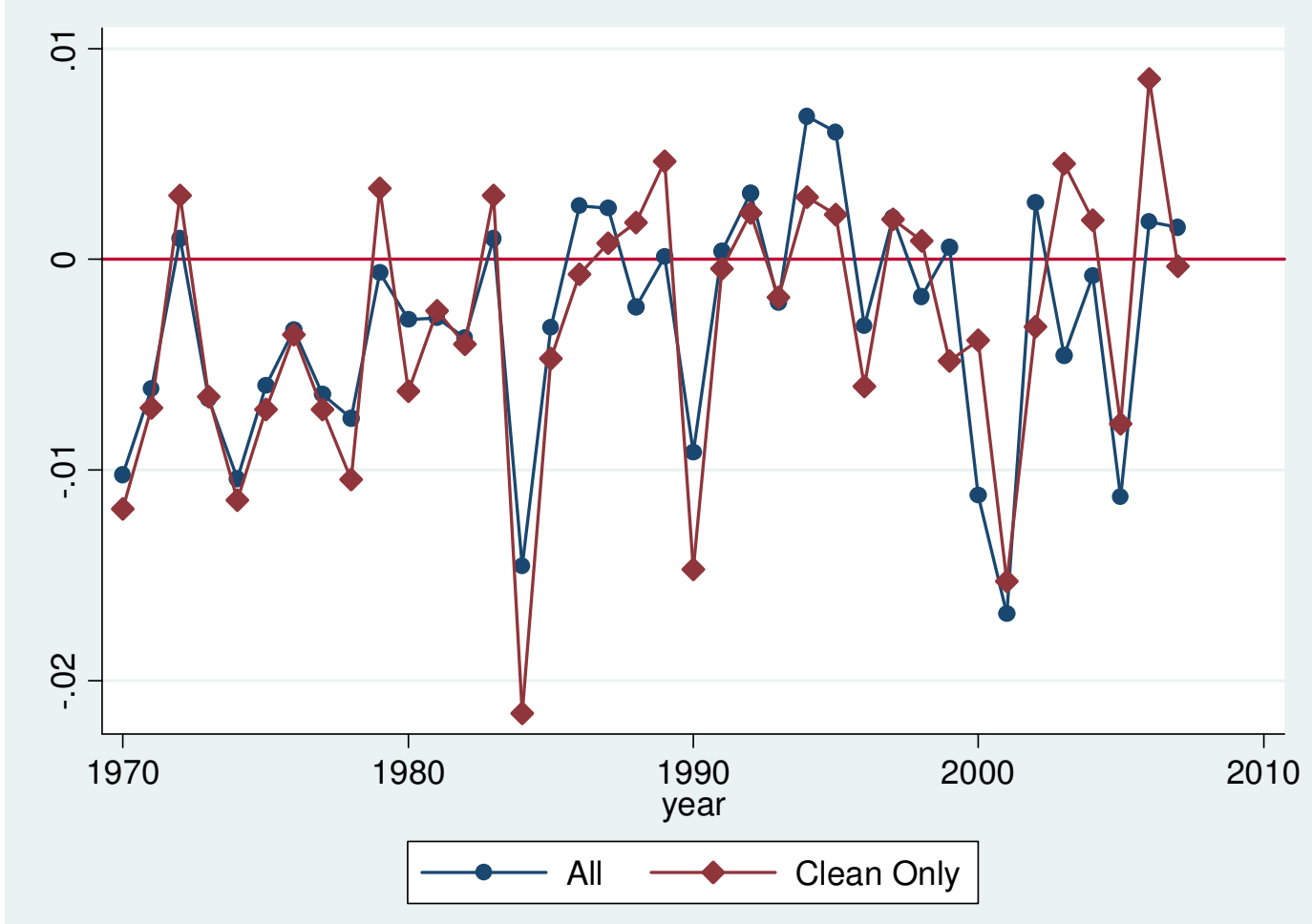

Source: Calculations by the authors using announcement information from the Wall Street Journal and data stock price data from the Center for Research in Security Prices (CRSP). 
Figure 8. Distribution of Cumulative Excess Returns by Decade

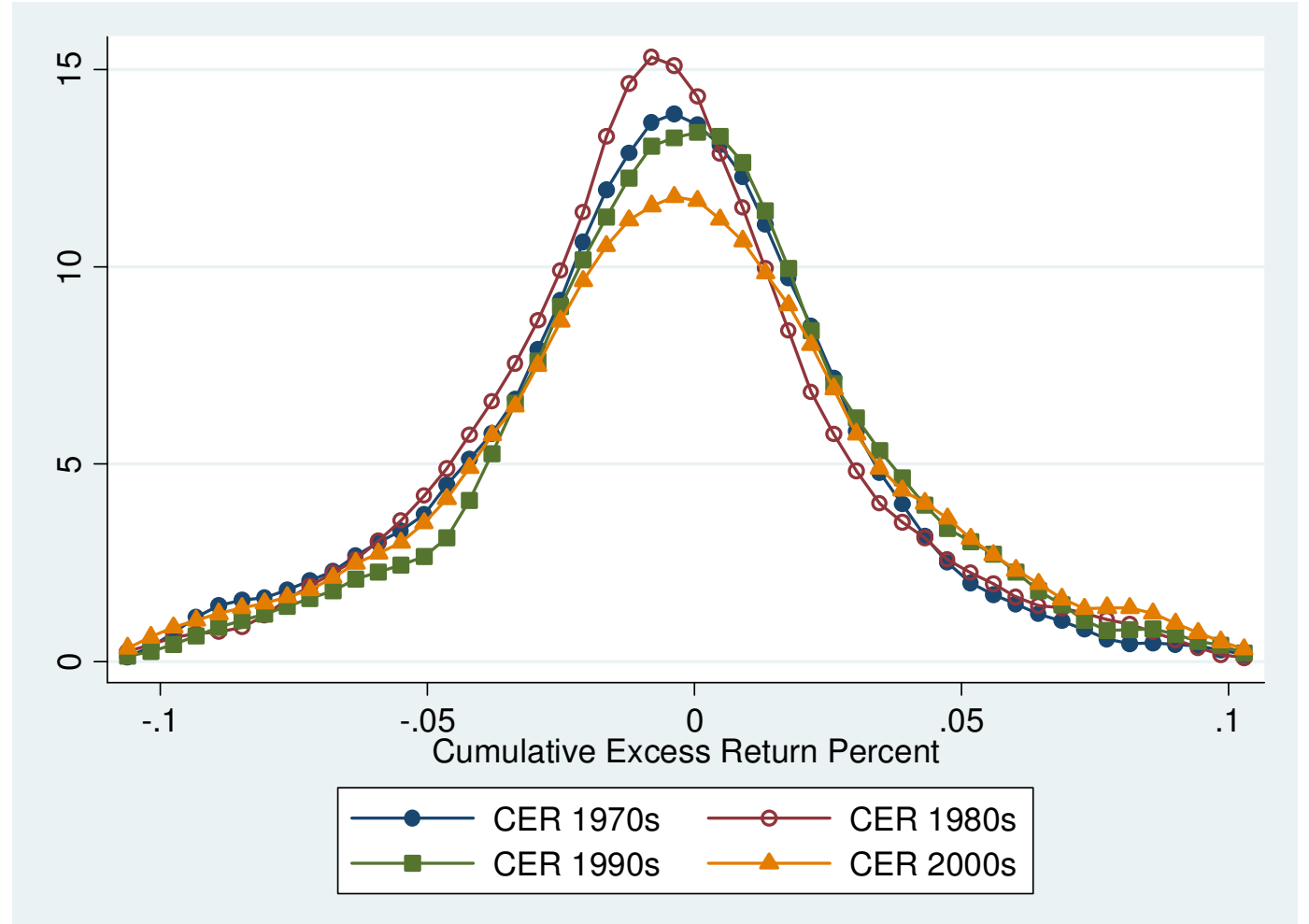

Source: Calculations by the authors using announcement information from the Wall Street Journal and data stock price data from the Center for Research in Security Prices (CRSP). 
Table 1. Data Sources on Job Loss

\begin{tabular}{llll}
\hline Source & Sample Size & Panel & Details \\
\hline $\begin{array}{l}\text { Current } \\
\begin{array}{l}\text { Population } \\
\text { Survey }\end{array}\end{array}$ & $\sim 60,000$ households & Short (1 year) & $\begin{array}{l}\text { Monthly survey (March is the most } \\
\text { commonly used month because it asks } \\
\text { respondents about income). The standard } \\
\text { source of US labor market data (e.g. } \\
\text { unemployment rate) }\end{array}$ \\
$\begin{array}{llll}\text { Displaced } \\
\text { Worker Survey }\end{array}$ & $\begin{array}{l}\text { A supplement to the CPS given every two } \\
\text { (All CPS households } \\
\text { are given the survey) }\end{array}$ & $\begin{array}{l}\text { Aears. Displacement is defined as follows } \\
\text { (via CPS website): "Persons 20 years of } \\
\text { age and older who lost or left jobs because } \\
\text { their plant or company closed or moved, } \\
\text { there was insufficient work for them to do, } \\
\text { or their position or shift was abolished" }\end{array}$
\end{tabular}

\begin{tabular}{|c|c|c|c|}
\hline $\begin{array}{l}\text { Health and } \\
\text { Retirement } \\
\text { Survey }\end{array}$ & 22,000 individuals & None & $\begin{array}{l}\text { Main focus is on health outcomes for } \\
\text { persons age } 50 \text { and over. Health status } \\
\text { verified by doctor. }\end{array}$ \\
\hline $\begin{array}{l}\text { Survey of } \\
\text { Income and } \\
\text { Program } \\
\text { Participation }\end{array}$ & $\begin{array}{l}\sim 14,000-37000 \\
\text { households }\end{array}$ & $\begin{array}{l}\text { Medium }(2.5-4 \\
\text { years })\end{array}$ & $\begin{array}{l}\text { Main focus is on federal/state/local income } \\
\text { transfer programs. }\end{array}$ \\
\hline $\begin{array}{l}\text { Panel Study of } \\
\text { Income } \\
\text { Dynamics }\end{array}$ & 9,000 households & $\begin{array}{l}\text { Long }(1968- \\
\text { present) }\end{array}$ & $\begin{array}{l}\text { Began in } 1968 \text { with } 4,000 \text { families. All } \\
\text { descendants of the originally surveyed } \\
\text { families are added to the sample. Detailed } \\
\text { demographic, human capital, and work } \\
\text { history information. }\end{array}$ \\
\hline $\begin{array}{l}\text { National } \\
\text { Longitudinal } \\
\text { Survey of Youth } \\
\text { (1979) }\end{array}$ & $\sim 13,000$ individuals & $\begin{array}{l}\text { Long }(1979- \\
\text { present) }\end{array}$ & $\begin{array}{l}\text { Respondents were } 14-22 \text { in } 1979 \text {. Detailed } \\
\text { demographic, human capital, and work } \\
\text { history information. }\end{array}$ \\
\hline $\begin{array}{l}\text { National } \\
\text { Longitudinal } \\
\text { Survey of Youth } \\
\text { (1997) }\end{array}$ & $\sim 9,000$ individuals & $\begin{array}{l}\text { Long }(1997- \\
\text { present) }\end{array}$ & $\begin{array}{l}\text { Respondents were } 12-16 \text { in } 1997 \text {. Detailed } \\
\text { demographic, human capital, and work } \\
\text { history information. }\end{array}$ \\
\hline $\begin{array}{l}\text { Longitudinal } \\
\text { Employer } \\
\text { Household } \\
\text { Dynamics }\end{array}$ & $\begin{array}{l}98 \% \text { of private, non- } \\
\text { farm employment }\end{array}$ & $\begin{array}{l}\text { Long }(1990- \\
\text { present) }\end{array}$ & $\begin{array}{l}\text { Linked employer-employee data. Quarterly } \\
\text { observations of earnings and job status. } \\
\text { Only basic demographic information is } \\
\text { available on workers. }\end{array}$ \\
\hline
\end{tabular}


Table 2. Distribution of Reasons for Announced Job Loss Announcements Over Time

\begin{tabular}{|c|c|c|c|c|c|}
\hline & $\begin{array}{c}\text { All } \\
\text { Years }\end{array}$ & 1970-1979 & (1980-1989 & 1990-1999 & $2000-2007$ \\
\hline Reorganization & 503 & 116 & 127 & 173 & 87 \\
\hline Restructuring & 315 & 37 & 96 & 143 & 39 \\
\hline Cost Control & 619 & 103 & 162 & 222 & 132 \\
\hline Slump in Demand & 1,855 & 568 & 588 & 365 & 334 \\
\hline Increased Competition & 99 & 20 & 20 & 45 & 14 \\
\hline Merger & 130 & 8 & 29 & 49 & 44 \\
\hline Restore Profitability & 71 & 16 & 16 & 16 & 23 \\
\hline Bankruptcy & 40 & 2 & 8 & & 30 \\
\hline Leaving Market & 134 & 54 & 32 & 27 & 21 \\
\hline In-House Merger & 11 & 0 & 3 & 4 & 4 \\
\hline Posting Losses & 259 & 107 & 97 & 41 & 14 \\
\hline Plant Closing & 303 & 66 & 84 & 71 & 82 \\
\hline Increase Earnings & 28 & 5 & 4 & 13 & 6 \\
\hline Excess Supply & 340 & 148 & 160 & 24 & 8 \\
\hline Structural & 30 & 13 & 9 & 8 & 0 \\
\hline Strike & 200 & 134 & 47 & 19 & 0 \\
\hline Other & 305 & 145 & 95 & 45 & 20 \\
\hline Missing & 111 & 37 & 38 & 32 & 4 \\
\hline
\end{tabular}

Source: Calculations by the authors using announcement information from the Wall Street Journal and data stock price data from the Center for Research in Security Prices (CRSP). 
Table 3. Effects of Layoffs on CEO Pay

Dependent Variable: Log Total CEO Compensation $^{\mathrm{a}}$

(1)

\begin{tabular}{lccc}
\hline (Any Layoff $)_{\mathrm{t}-1}$ & $\begin{array}{c}0.378^{* * *} \\
(0.048)\end{array}$ & $0.134 * * *$ & -0.050 \\
& & $(0.044)$ & $(0.036)$ \\
$\log ($ market value of equity $)$ & & $0.319 * * *$ & $0.534 * * *$ \\
& - & $(0.012)$ & $(0.033)$ \\
$(\text { Annual Return })_{\mathrm{t}-1}$ & & $0.149 * * *$ & $0.070 * * *$ \\
& - & $(0.034)$ & $(0.026)$ \\
Other Regressors & no & yes & yes \\
Company Indicators & no & no & yes \\
$\mathrm{R}^{2}$ & 0.019 & 0.252 & 0.693 \\
\hline
\end{tabular}

${ }^{a}$ Total compensation is the sum of salary, bonus, other compensation and exercised options.

${ }^{\mathrm{b}}$ Other regressors are age of the CEO and its square, seniority of the CEO and its square and yearly indicators variables.

***significantly different from 0 at the $1 \%$ level.

Sample size is 3,242. Standard errors are in parentheses.

Source: Hallock (1998) 
Table 4. Are Excess Price Reactions to Layoffs Explained by "Reasons” or Time?

\begin{tabular}{|c|c|c|c|c|c|c|}
\hline & (1) & (2) & (3) & (4) & (5) & (6) \\
\hline & \multicolumn{2}{|c|}{$1970-2007$} & 1970-1979 & 1980-1989 & 1990-1999 & $2000-2007$ \\
\hline Constant & $\begin{array}{c}-0.654 * * * \\
(0.132)\end{array}$ & $\begin{array}{l}-0.403 \\
(0.327)\end{array}$ & $\begin{array}{c}-0.269 \\
(0.494)\end{array}$ & $\begin{array}{l}-0.046 \\
(0.562)\end{array}$ & $\begin{array}{c}0.683 \\
(0.721)\end{array}$ & $\begin{array}{c}-2.061 * * \\
(1.022)\end{array}$ \\
\hline 1980-1989 & $\begin{array}{c}0.423 * * \\
(0.186)\end{array}$ & $\begin{array}{c}0.311 * * \\
(0.126)\end{array}$ & & & & \\
\hline 1990-1999 & $\begin{array}{c}0.664 * * * \\
(0.199)\end{array}$ & $\begin{array}{c}0.458 * * * \\
(0.135)\end{array}$ & & & & \\
\hline $2000-2007$ & $\begin{array}{l}-0.109 \\
(0.235)\end{array}$ & $\begin{array}{c}0.083 \\
(0.174)\end{array}$ & & & & \\
\hline \multicolumn{7}{|l|}{ Reason } \\
\hline Reorganization & & $\begin{array}{c}0.456 \\
(0.344)\end{array}$ & $\begin{array}{c}0.223 \\
(0.558)\end{array}$ & $\begin{array}{c}0.348 \\
(0.606)\end{array}$ & $\begin{array}{c}-0.154 \\
(0.751)\end{array}$ & $\begin{array}{c}2.472 * * \\
(1.105)\end{array}$ \\
\hline Plant Closing & & $\begin{array}{c}0.192 \\
(0.329)\end{array}$ & $\begin{array}{c}0.313 \\
(0.559)\end{array}$ & $\begin{array}{c}0.389 \\
(0.631)\end{array}$ & $\begin{array}{l}-1.182 \\
(0.848)\end{array}$ & $\begin{array}{c}1.664 \\
(1.127)\end{array}$ \\
\hline Demand & & -0.206 & -0.244 & -0.298 & -0.881 & 1.440 \\
\hline Slump & & $(0.342)$ & $(0.508)$ & $(0.578)$ & $(0.746)$ & $(1.057)$ \\
\hline Cost & & $\begin{array}{l}-0.004 \\
(0.342)\end{array}$ & $\begin{array}{l}-0.427 \\
(0.539)\end{array}$ & $\begin{array}{l}-0.027 \\
(0.604)\end{array}$ & $\begin{array}{l}-0.536 \\
(0.756)\end{array}$ & $\begin{array}{l}2.009^{*} \\
(1.087)\end{array}$ \\
\hline Other & & $\begin{array}{c}0.327 \\
(0.343)\end{array}$ & $\begin{array}{c}0.106 \\
(0.520)\end{array}$ & $\begin{array}{c}0.297 \\
(0.609)\end{array}$ & $\begin{array}{l}-0.165 \\
(0.783)\end{array}$ & $\begin{array}{l}2.181^{*} \\
(1.113)\end{array}$ \\
\hline $\begin{array}{l}\mathrm{p} \text {-value } \\
\text { Decade }=0\end{array}$ & 0.001 & 0.004 & & & & \\
\hline $\begin{array}{l}\text { p-value } \\
\text { Reason }=0\end{array}$ & & 0.0001 & 0.095 & 0.054 & 0.065 & 0.131 \\
\hline $\mathrm{R}^{2}$ & 0.003 & 0.007 & 0.003 & 0.004 & 0.005 & 0.005 \\
\hline $\mathrm{N}$ & 4907 & 4907 & 1515 & 1515 & 1183 & 694 \\
\hline
\end{tabular}

Standard errors are reported in parentheses. Observations are weighted by the inverse of the standard error of the cumulative excess return. The base category is the 1970-1979 period due to "missing" reasons. 